\title{
Analyst
}

\section{Rationally designed haptens for highly sensitive monoclonal antibody-based immunoanalysis of fenhexamid}

\begin{tabular}{|r|l|}
\hline Journal: & Analyst \\
\hline Manuscript ID & AN-ART-05-2018-000827.R1 \\
\hline Article Type: & Paper \\
\hline Date Submitted by the Author: & n/a \\
\hline Complete List of Authors: & $\begin{array}{l}\text { Esteve-Turrillas, Francesc; Universitat de Valencia, Analytical Chemistry } \\
\text { Departament } \\
\text { Agulló, Consuelo; Universitat de València, Organic Chemistry Department } \\
\text { Mercader, Josep; IATA-CSIC, } \\
\text { Abad-Somovilla, Antonio; Universitat de València, Organic Chemistry } \\
\text { Department } \\
\text { Abad-Fuentes, Antonio; IATA-CSIC, }\end{array}$ \\
\hline
\end{tabular}




\title{
Journal Name
}

\section{Rationally designed haptens for highly sensitive monoclonal antibody-based immunoanalysis of fenhexamid}

Received 00th January 20xx, Accepted 00th January 20xx

DOI: $10.1039 / x 0 x \times 00000 x$

www.rsc.org/

\author{
Francesc A. Esteve-Turrillas, ${ }^{a}$ Consuelo Agulló, ${ }^{b}$ Josep V. Mercader, ${ }^{a}$ A. Abad-Somovilla ${ }^{b}$ and A. \\ Abad-Fuentes ${ }^{a,+}$
}

\begin{abstract}
Immunochemical methods have been consolidated during the last years as complementary analytical strategies for chemical contaminant and residue determination. However, generation of suitable immunoreagents for small organic molecules demands adequate hapten design. In this study, fenhexamid was considered as a model compound and novel haptens were designed and synthesized in order to evaluate the influence of the linker tethering site on antibody binding properties and immunoassay parameters. Haptens were conceived with the spacer arm at different positions while the more antigenic aromatic moiety was kept free. The synthesis of these functionalized compounds was accomplished by total construction of the molecule through several steps. This strategy afforded very high-affinity monoclonal antibodies specific of fenhexamid, with $\mathrm{IC}_{50}$ values around or below $0.1 \mathrm{nM}$. Using these novel immunoreagents, a direct competitive enzyme-linked immunosorbent assay with a remarkably low limit of detection $\left(4 \mathrm{ng} \mathrm{L}^{-1}\right)$ was developed for the determination of fenhexamid residues. The selected immunoassay was investigated in terms of trueness, precision, repeatability, and robustness. The QuEChERS extraction methodology was applied to fortified samples and recoveries between $83 \%$ and $113 \%$, with relative standard deviations below $20 \%$, were observed. Moreover, contaminated and blind spiked samples were measured by the developed immunoassay and by ultra-performance liquid chromatography coupled to tandem mass spectrometry, showing statistically comparable results.
\end{abstract}

\section{Introduction}

1,4-Hydroxyanilides comprise a family of modern biocide compounds with varied toxicological and degradation patterns, which depend on the properties of the aromatic substituent. ${ }^{1}$ Among this group, fenhexamid ( $\mathrm{N}$-(2,3-dichloro4-hydroxyphenyl)-1-methylcyclohexanecarboxamide) has reached high commercial significance as fungicide due to its low persistence and high efficiency. Analysis of chemical residues and contaminants is commonly performed by chromatographic determination with spectrometry detection, commonly coupled to the QuEChERS (Quick, Easy, Cheap, Effective, Rugged, and Safe) extraction procedure. ${ }^{2,3}$ By using either gas $^{4,5}$ or liquid ${ }^{6-8}$ chromatography coupled to mass spectrometry detection, limits of quantification (LOQ) in the 1$10 \mu \mathrm{g} \mathrm{kg}^{-1}$ range were achieved. Although chromatographic

\footnotetext{
a. Institute of Agrochemistry and Food Technology, Spanish Council for Scientific Research (IATA-CSIC), Agustí Escardino 7, Paterna 46980, València, Spain.

${ }^{b .}$ Department of Organic Chemistry, University of Valencia, Doctor Moliner 50, Burjassot 46100, València, Spain.

† Corresponding author email: aabad@iata.csic.es.

Electronic Supplementary Information (ESI) available: General methods and instruments, experimental details of hapten synthesis, MALDI-TOF spectra of bioconjugates (Figure S1), checkerboard titration of antibodies (Table S1), precision of the standard curve (Table S2), matrix effects (Figure S2), determination of fenhexamid in contaminated samples by CELISA and UPLC-MS (Table S3), ${ }^{1} \mathrm{H}$ NMR spectra of haptens $\mathrm{FHm}, \mathrm{FHd}$ and $\mathrm{FH} h$ and their NHS-esters. See DOI: $10.1039 / \mathrm{x} 0 \times x \times 0000 x$
}

methods are sensitive, selective, and precise, they are timeconsuming and require expensive equipment. Therefore, immunoassays have been frequently proposed as a valuable complementary method in order to improve sample throughput, thus reducing time and costs, while maintaining high analytical performance.

Antibody and bioconjugate properties determine the good performance of immunochemical methods dealing with small organic molecules, such as fenhexamid. Ultimately, immunoreagent generation with adequate binding features is strongly influenced by the structure of the immunizing chemical (hapten) that is employed in bioconjugate preparation. $^{9-12}$ Designed haptens usually consist of a molecular scaffold mimicking the target compound, a spacer arm, and a reactive or activatable chemical group for coupling to the carrier macromolecule. Immunizing haptens should resemble as much as possible the electronic distribution and steric properties of the target substance. In general, it is recommended not to modify important immunodeterminant groups or any other moieties that are characteristic of the target compound. ${ }^{13}$ Introduction of the spacer arm at a distal position from those relevant moieties, as already pointed out by Nobel Price Karl Landsteiner in $1962,{ }^{14}$ is a well-known strategy. Linker properties, such as length, composition, and particularly the tethering site, are fundamental structural parameters which may influence the physicochemical 


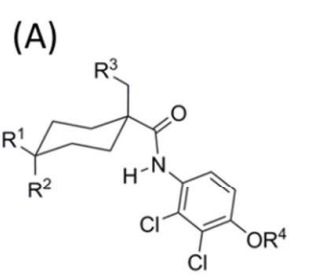

Fenhexamid: $\mathrm{R}^{1}=\mathrm{R}^{2}=\mathrm{R}^{3}=\mathrm{R}^{4}=\mathrm{H}$ Hapten FHo: $\mathrm{R}^{1}=\mathrm{R}^{2}=\mathrm{R}^{3}=\mathrm{H} ; \mathrm{R}^{4}=\left(\mathrm{CH}_{2}\right)_{3} \mathrm{CO}_{2} \mathrm{H}$ Hapten $\mathrm{FH} m: \mathrm{R}^{1}=\mathrm{R}^{2}=\mathrm{R}^{4}=\mathrm{H} ; \mathrm{R}^{3}=\left(\mathrm{CH}_{2}\right)_{4} \mathrm{CO}_{2} \mathrm{H}$ Hapten $\mathrm{FH} h: \mathrm{R}^{1}=\left(\mathrm{CH}_{2}\right)_{4} \mathrm{CO}_{2} \mathrm{H} ;, \mathrm{R}^{2}=\mathrm{R}^{3}=\mathrm{R}^{4}=\mathrm{H}$ Hapten FHd: $\mathrm{R}^{1}, \mathrm{R}^{2}=\mathrm{CH}\left(\mathrm{CH}_{2}\right)_{3} \mathrm{CO}_{2} \mathrm{H} ; \mathrm{R}^{3}=\mathrm{R}^{4}=\mathrm{H}$

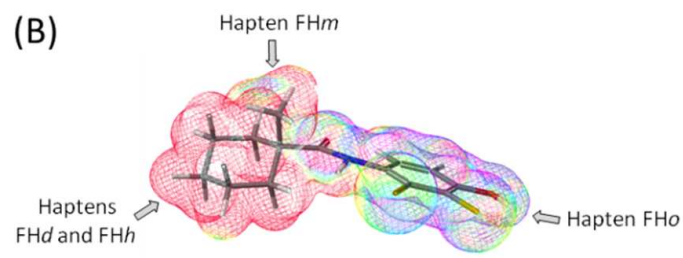

Fig. 1 (A) Chemical structure of fenhexamid and the prepared haptens. (B) Electron density surface coloured by electrostatic potential of the most stable conformation of fenhexamid. The surface is coloured to reflect the electrostatic potential at every point on the surface; colour alteration from red to blue describes the shift from an electronpoor region to an electron-rich one. The energy values [in atomic units (au)] at each colour interface are: white-red, +0.09 au; red-yellow, +0.02 au; yellow-green, +0.01 au; green-light blue, $0.00 \mathrm{au}$; light blue-dark blue, $-0.01 \mathrm{au}$; dark blue-pink, $-0.03 \mathrm{au}$; pink-violet, $-0.06 \mathrm{au}$; where $1 \mathrm{au}=627.503 \mathrm{kcal} \mathrm{mol}-1$. Arrows denote the spacer-arm attachment site in each of the haptens.

characteristics of the hapten, and eventually the adequate display of the molecule to the medium.

Due to incomplete knowledge about antigen-antibody interaction mechanisms, most hapten designs are based on previous scientific experience and trial-and-error approaches. However, during the last years, researchers have focused on theoretical assessment relying upon empirical results. ${ }^{15-16}$ Computer-assisted molecular modelling (CAMM) techniques are potent tools for rational chemical design, which may help immunochemists to discover the most suitable hapten structure for immunizing conjugate and antigen preparation. Moreover, CAMM-based structure-activity relationship analyses can contribute to better understand affinity and specificity characteristics of the produced biomolecules. ${ }^{17-18}$ Structurally, the fenhexamid framework is made up by an amido bridge that links an aliphatic moiety to an aromatic group (Fig. 1). The fenhexamid framework may adopt several low-energy conformations associated to the restriction of rotation around the planar amide bond and to the chair-chair conformational equilibrium of the cyclohexane ring. Two conformers of fenhexamid have been observed in the solid phase, by crystallization of fenhexamid in tetrahydrofuran and X-ray analysis, one with an axially oriented phenylcarbamoyl group and the other with this group in an equatorial disposition, in a ratio of $55: 45 .^{1}$ The last of these conformations is similar to the minimum energy conformation calculated by Molecular Mechanics (Figure 1B). Functionalization of fenhexamid for bioconjugation can readily be accomplished by derivatization of the phenolic hydroxyl oxygen with a properly functionalized alkyl halide. With such a tethering site, the distal and less immunogenic aliphatic groups could be preferentially displayed. Moderate-affinity antibodies to fenhexamid were produced before using such strategy. ${ }^{19}$
The aim of the present study was to evaluate the structure-activity relationship of different haptens for the generation of high-affinity monoclonal antibodies to fenhexamid. Novel functionalized derivatives were conceived in which the dichlorohydroxyanilide aromatic moiety would be preferentially displayed by placing the spacer arm at the opposite site of the molecule, thus favouring $\pi$-staking and hydrophobic interactions as well as formation of hydrogen bonds, and consequently increasing antibody affinity. Moreover, the development of a highly sensitive competitive enzyme-linked immunosorbent assay (cELISA) for the determination of fenhexamid residues in vegetables was studied. The proposed immunoassay was validated by comparison with ultra-performance liquid chromatography tandem mass spectrometry analysis (UPLC-MS/MS).

\section{Experimental}

\section{Reagents and instrumentation}

Chemical reagents used for hapten synthesis were acquired from commercial sources and used without purification. Ethyl 1,4-dioxaspiro[4.5]decane-8-carboxylate (10) was prepared as described by Barrios ${ }^{20}$ and 4-(benzyloxy)-2,3-dichloroaniline (4) was prepared in three steps from 4-amino-2,3-dichlorophenol as described in the ESI. ${ }^{+}$Solvents were purified by distillation and, if required, they were dried according to standard methods. Primary-secondary amine (PSA) was obtained from Varian (Lake Forest, CA, USA). Fraction $V$ bovine serum albumin (BSA) and Hybridoma Fusion and Cloning Supplement (HFCS) were purchased from Roche Applied Science (Mannheim, Germany). Horseradish peroxidase (HRP), ovalbumin (OVA), Freund's adjuvants, foetal bovine serum, ophenylenediamine, and triphenyl phosphate (TPP) were purchased from Sigma/Aldrich (Madrid, Spain). P3-X63-Ag 8.653 mouse plasmacytoma cell line was from the European Collection of Cell Cultures (Wiltshire, UK). HiTrap Desalting Sephadex G-25 and HiTrap Protein G HP columns were acquired from GE Healthcare (Uppsala, Sweden) and operated under an ÄKTA Purifier workstation. Fenhexamid and other fungicide standards were purchased from Fluka/Riedel-deHaën (Seelze, Germany) or Dr. Ehrenstorfer (Augsburg, Germany). Working standard solutions were prepared as concentrated solutions in acetonitrile and kept at $-20{ }^{\circ} \mathrm{C}$ in amber glass vials. Costar ${ }^{\mathrm{TM}}$ flat-bottom high-binding polystyrene ELISA plates were from Corning (Corning, NY, USA). ELISA plates were washed with an ELX405 microplate washer from BioTek Instruments (Winooski, VT, USA). Ultraviolet-visible spectra and ELISA absorbances were read with a PowerWave HT also from BioTek Instruments. A T-25 ultra-turrax blender and a vortex mixer Ms2 from IKA (Staufen, Germany), as well as an Eppendorf 5804 centrifuge (Hamburg, Germany) were employed for the extraction of vegetables.

\section{Molecular modelling}

Calculations were performed using Molecular Mechanics (MM3) as implemented in the CAChe program [CAChe 


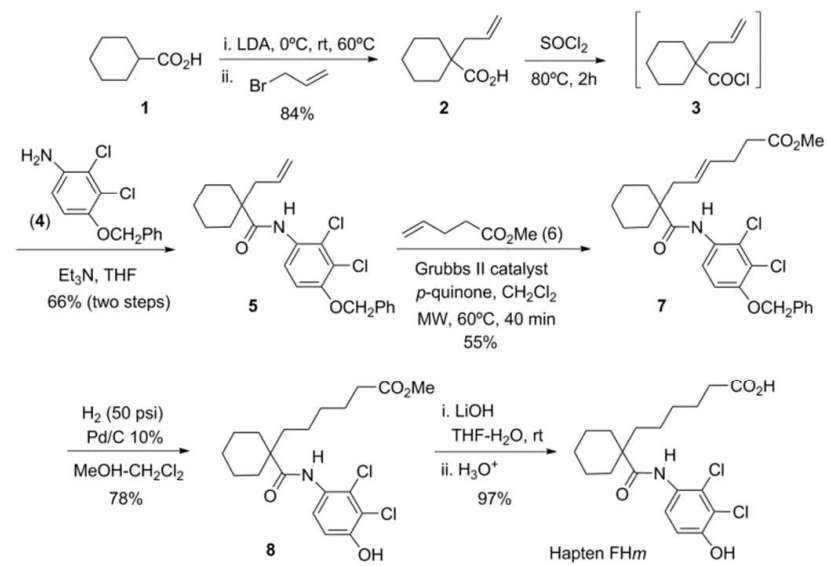

Fig. 2 Synthesis of hapten $\mathrm{FHm}$.

WorkSystem Pro software, version 7.5.0.85 (Fujitsu Ltd, Tokyo, Japan)]. A systematic conformational search was performed (all rotatable bonds were rotated by 24 degree steps) and the geometry of the generated conformers was refined by performing an optimized geometry calculation in MOPAC using PM3 parameters.

\section{Hapten synthesis}

The haptens that were used for the preparation of immunogen and coating conjugates were synthesized according to the synthetic pathways depicted in Figs. 2 and 3. The spectroscopic characterization data of the intermediates of the synthesis are given in the ESI. ${ }^{+}$

\section{Preparation of hapten $\mathrm{FHm}$}

Synthesis of 1-allylcyclohexanecarboxylic acid (2). ${ }^{21}$ A solution of acid 1 (668 mg, $5.21 \mathrm{mmol}$ ) in anhydrous THF $(3.2 \mathrm{~mL}$ ) was dropwise added into a $0.52 \mathrm{M}$ solution of LDA in THF-hexane (24.1 mL, $13.1 \mathrm{mmol}, 2.5$ equiv; prepared from $8.2 \mathrm{~mL}$ of $1.6 \mathrm{M}$ BuLi in hexane and $2.0 \mathrm{~mL}$ of diisopropylamine in $13.9 \mathrm{~mL}$ of THF) cooled at $0{ }^{\circ} \mathrm{C}$ under nitrogen atmosphere. The reaction mixture was stirred at this temperature for $45 \mathrm{~min}$, then at room temperature (rt) for $1 \mathrm{~h}$ and at $60{ }^{\circ} \mathrm{C}$ for $30 \mathrm{~min}$. After this time, the reaction mixture was cooled to $0{ }^{\circ} \mathrm{C}$ and then freshly distilled allyl bromide ( $1.108 \mathrm{~mL}, 12.0 \mathrm{mmol}, 2.3$ equiv)
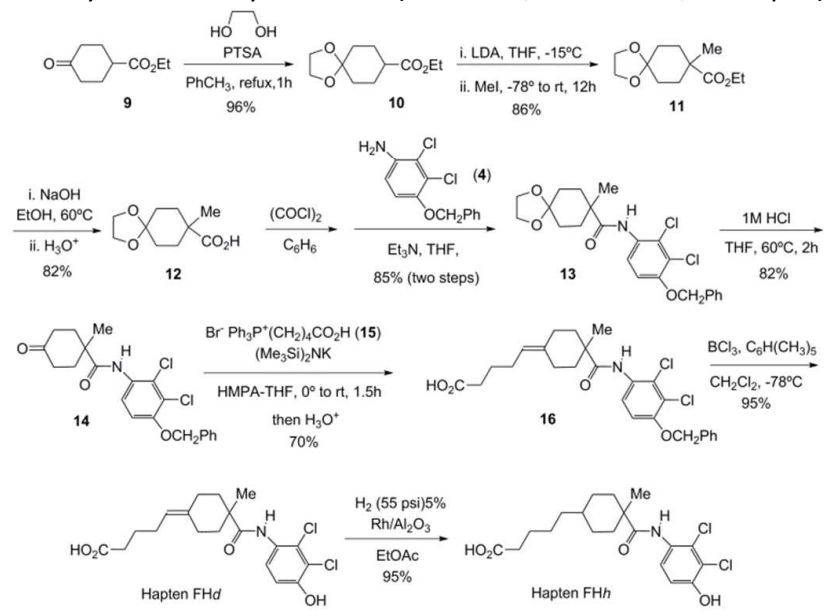

Fig. 3 Synthesis of haptens $\mathrm{FH} d$ and FHh. was added and the mixture stirred at rt overnight. The reaction mixture was cooled to $0{ }^{\circ} \mathrm{C}$, then quenched by the addition of a saturated aqueous solution of $\mathrm{NH}_{4} \mathrm{Cl}(5 \mathrm{~mL})$ and acidified with $2 \mathrm{M} \mathrm{H}_{2} \mathrm{SO}_{4}$ to $\mathrm{pH}$ 1-2. The mixture was extracted with $\mathrm{Et}_{2} \mathrm{O}$ and the ethereal layers were extracted with a $10 \%(\mathrm{w} / \mathrm{v})$ aqueous solution of $\mathrm{Na}_{2} \mathrm{CO}_{3}$. The combined aqueous layers were cooled to $0{ }^{\circ} \mathrm{C}$, acidified to $\mathrm{pH} 3$ with $6 \mathrm{M} \mathrm{H}_{2} \mathrm{SO}_{4}$, and extracted with $\mathrm{Et}_{2} \mathrm{O}$. The combined organic layers were washed with brine, dried over anhydrous $\mathrm{MgSO}_{4}$, filtered, and concentrated under vacuum to give the acid 2 ( $737 \mathrm{mg}, 84 \%$ ) as an oil, which was determined to be essentially pure by ${ }^{1} \mathrm{H}$ NMR. This material was subsequently employed directly without further purification.

Synthesis of 1-allyl-N-(4-(benzyloxy)-2,3dichlorophenyl)cyclohexanecarboxamide (5). A solution of acid 2 (123 mg, $0.785 \mathrm{mmol})$ in $\mathrm{SOCl}_{2}(1 \mathrm{~mL})$ was stirred under anhydrous conditions at reflux for $2 \mathrm{~h}$. Evaporation of the excess of $\mathrm{SOCl}_{2}$ under vacuum afforded the intermediate carboxylic acid chloride 3 (146.5 $\mathrm{mg}, 0.784 \mathrm{mmol}$ ), which was dissolved in anhydrous THF $(2.5 \mathrm{~mL})$ and cooled in a water-ice bath under nitrogen. $\mathrm{Et}_{3} \mathrm{~N}(328 \mu \mathrm{L}, 2.35 \mathrm{mmol})$ and a solution of aniline 4 (178 $\mathrm{mg}, 0.664 \mathrm{mmol})$ in THF $(2.5 \mathrm{~mL})$ were then added, and the mixture stirred at $\mathrm{rt}$ for $5 \mathrm{~h}$, then poured into water and extracted with $\mathrm{Et}_{2} \mathrm{O}$. The combined organic layers were washed with brine and dried over anhydrous $\mathrm{Na}_{2} \mathrm{SO}_{4}$. Chromatography of the residue left after evaporation of the solvent under reduced pressure, using hexane/EtOAc mixtures from 95:5 to 70:30 as eluent, afforded the amide $5(183.1 \mathrm{mg}$, $66 \%$ overall yield from 2 ) as an oil.

Synthesis of (E)-methyl 6-(1-((4-(benzyloxy)-2,3dichlorophenyl)carbamoyl)cyclohexyl) hex-4-enoate (7). A solution of $p$-quinone $(7 \mathrm{mg}, 0.065 \mathrm{mmol})$, Grubbs secondgeneration catalyst [(1,3-dimesityl-2imidazolylidene) $\left.\left(\mathrm{PCy}_{3}\right) \mathrm{Cl}_{2} \mathrm{RuCHPh}\right]$ (18.3 $\mathrm{mg}, 0.021 \mathrm{mmol}$ ), methyl 4-pentenoate $(73.7 \mathrm{mg}, 0.64 \mathrm{mmol})$, and amide 5 (90 $\mathrm{mg}, 0.215 \mathrm{mmol}$ ) in degassed anhydrous $\mathrm{CH}_{2} \mathrm{Cl}_{2}(3 \mathrm{~mL})$ was placed in a microwave tube under a $\mathrm{N}_{2}$ atmosphere. The reaction mixture was then heated using a microwave oven at $60{ }^{\circ} \mathrm{C}$ for $40 \mathrm{~min}$. The solvent was removed under vacuum and the obtained residue was chromatographed, using hexane $/ \mathrm{CH}_{2} \mathrm{Cl}_{2}$ 1:1 as eluent, to afford, in order of elution, unreacted starting material (35.1 mg, 39\%) and alkene 7 (59.7 $\mathrm{mg}, 55 \%$; $90 \%$ based on recovered starting material). In some cases, compound $\mathbf{7}$ was obtained as a slightly coloured oil (blue), due to catalyst impurities, and a second chromatographic purification, using $\mathrm{CH}_{2} \mathrm{Cl}_{2}$ as eluent, was required to obtain a colourless product.

Synthesis of methyl 6-(1-((2,3-dichloro-4hydroxyphenyl)carbamoyl)cyclohexyl)hexanoate (8). A mixture of compound $7(56.8 \mathrm{mg}, 0.112 \mathrm{mmol}$ ) and $10 \% \mathrm{Pd} / \mathrm{C}$ (8 mg) in $10: 1 \mathrm{MeOH} / \mathrm{CH}_{2} \mathrm{Cl}_{2}(4.5 \mathrm{~mL})$ was stirred under an atmosphere of hydrogen at $50 \mathrm{psi}$ for $9 \mathrm{~h}$. The reaction mixture was filtered through a short silica gel column, using $\mathrm{MeOH}$ as the eluent, and the residue obtained after concentration of the filtrate was chromatographed on silica gel, using $\mathrm{CHCl}_{3} /$ EtOAC 9:1 as eluent, to give the phenol $8(36.6 \mathrm{mg}, 78 \%)$ as a colourless oil. 
Synthesis

of

6-(1-)(2,3-dichloro-4hydroxyphenyl)carbamoyl)cyclohexyl)hexanoic acid (hapten FHm). LiOH (19.2 mg, $0.457 \mathrm{mmol}$ ) was added to a solution of methyl ester 8 (19 $\mathrm{mg}, 0.046 \mathrm{mmol}$ ) in a mixture of THF (360 $\mu \mathrm{L})$ and $\mathrm{H}_{2} \mathrm{O}(160 \mu \mathrm{L})$. The resulting reaction mixture was stirred at $\mathrm{rt}$ for $3 \mathrm{~h}$, diluted with water, and acidified with an aqueous solution of $\mathrm{KHSO}_{4}$. The mixture was extracted with $\mathrm{Et}_{2} \mathrm{O}$ and the combined organic layers were washed with brine, dried over anhydrous $\mathrm{MgSO}_{4}$, and concentrated under vacuum to give hapten $\mathrm{FHm}(17.9 \mathrm{mg}, 97.3 \%)$ as a white solid. $\mathrm{Mp} 133-$ $137{ }^{\circ} \mathrm{C}$ (from cold MeOH); IR $v_{\max }\left(\mathrm{cm}^{-1}\right)(\mathrm{KBr}) 3500-2500$, 3412, 3320, 2931, 1701, 1654, 1518, 1284; ${ }^{1} \mathrm{H}$ NMR $(300 \mathrm{MHz}$, $\left.\mathrm{CD}_{3} \mathrm{OD}\right) \delta(\mathrm{ppm}) 7.17(1 \mathrm{H}, \mathrm{d}, J=8.8 \mathrm{~Hz}, \mathrm{H}-6 \mathrm{Ph}), 6.89(1 \mathrm{H}, \mathrm{d} J=$ $8.8 \mathrm{~Hz}, \mathrm{H}-5 \mathrm{Ph}), 2.28(2 \mathrm{H}, \mathrm{t}, J=7.3 \mathrm{~Hz}, \mathrm{H}-2), 2.16(2 \mathrm{H}, \mathrm{H}-2 / \mathrm{H}-6$ Cy), 1.7-1.5 (8H, m), 1.45-1.3 (8H, m); ${ }^{13} \mathrm{C}$ NMR (75 MHz, THF$\left.\mathrm{d}_{8}\right) \delta(\mathrm{ppm}) 174.7\left(\mathrm{CO}_{2} \mathrm{H}\right), 174.6(\mathrm{CON}), 152.6(\mathrm{C} 4-\mathrm{Ph}), 129.9$ (C1-Ph), 127.1 (C2-Ph), 125.2 (C6-Ph), 120.2 (C3-Ph), 115.3 (C5$\mathrm{Ph}), 48.1$ (C1-Cy), 35.5 (C2/C6-Cy), 34.4 (C6), 34.3 (C2), 30.0 (C4), 27.3 (C4-Cy), 25.9 (C3), 24.9 (C5), 24.2 (C3/C5-Cy); HRMS (TOF MS ES-) calcd for $\mathrm{C}_{19} \mathrm{H}_{24} \mathrm{Cl}_{2} \mathrm{NO}_{4}[\mathrm{M}-\mathrm{H}]^{-} 400.1082$, found 400.1082. UV (100 mM sodium phosphate buffer, $\mathrm{pH} 7.4$ ), $\varepsilon$ $(280 \mathrm{~nm})=1.82 \mathrm{mM}^{-1} \mathrm{~cm}^{-1}$.

\section{Preparation of haptens $\mathrm{FH} d$ and $\mathrm{FH} h$}

Synthesis of ethyl 8-methyl-1,4-dioxaspiro[4.5]decane-8carboxylate (11). A solution of ester $10(1.182 \mathrm{~g}, 5.51 \mathrm{mmol})$ in anhydrous THF ( $8 \mathrm{~mL}$ ) was added dropwise over $1 \mathrm{~h}$ into a solution of LDA [prepared from $4.6 \mathrm{~mL}$ of a $1.56 \mathrm{M}$ solution of BuLi in hexanes $(7.17 \mathrm{mmol}, 1.3$ equiv) and $1 \mathrm{~mL}$ of diisopropylamine $(0.726 \mathrm{mg}, 7.17 \mathrm{mmol}, 1.3$ equiv)] in THF (8 $\mathrm{mL}$ ) at $-78{ }^{\circ} \mathrm{C}$ under argon atmosphere. The reaction mixture was stirred at the same temperature for $1.5 \mathrm{~h}$, allowed to warm slowly to $-15^{\circ} \mathrm{C}$, and then stirred for a further $30 \mathrm{~min}$. The reaction mixture was cooled again to $-78^{\circ} \mathrm{C}$, then treated with $\mathrm{CH}_{3} \mathrm{l}$ ( $1.56 \mathrm{~g}, 0.69 \mathrm{~mL}, 11.02 \mathrm{mmol}, 2$ equiv), stirred at this temperature for $1 \mathrm{~h}$, and then allowed to be gradually warmed to $\mathrm{rt}$ and stirred overnight, after which, it was poured into water and extracted with $\mathrm{Et}_{2} \mathrm{O}$. The combined organic layers were washed with brine, dried over anhydrous $\mathrm{MgSO}_{4}$, filtered, and concentrated under vacuum to yield an oil that was purified by column chromatography, using a mixture of hexane/EtOAc (from 100:0 to $80: 20$ ) as eluent, to give compound $11(1.082 \mathrm{~g}, 86 \%)$ as a colourless oil. ${ }^{22-24}$

Synthesis of 8-methyl-1,4-dioxaspiro[4.5]decane-8-carboxylic acid (12). A solution of ethyl ester 11 (364.6 mg, $1.597 \mathrm{mmol}$ ) in a mixture of EtOH $(7.3 \mathrm{~mL})$ and a $5 \mathrm{M}$ aqueous solution of $\mathrm{NaOH}\left(0.8 \mathrm{~mL}, 4.0 \mathrm{mmol}, 2.5\right.$ equiv) was stirred at $60^{\circ} \mathrm{C}$ for 3.5 h. After cooling to $\mathrm{rt}$, the reaction mixture was diluted with water, extracted with $\mathrm{Et}_{2} \mathrm{O}$, and the aqueous layer cooled in an ice-water bath and carefully acidified with an aqueous solution of $\mathrm{KHSO}_{4}$ to $\mathrm{pH} 4-5$. The mixture was extracted with $\mathrm{Et}_{2} \mathrm{O}$ and the combined organic layers were washed with water and brine, dried over anhydrous $\mathrm{Na}_{2} \mathrm{SO}_{4}$, and concentrated under reduced pressure to afford the acid $12(262.5 \mathrm{mg}, 82 \%)$ as a foam that was used in the next step without further purification.
Synthesis of $\mathbf{N}$-(4-(benzyloxy)-2,3-dichlorophenyl)-8-methyl1,4-dioxaspiro[4.5]decane-8-carboxamide (13). A $2 \mathrm{M}$ solution of oxalyl chloride in $\mathrm{CH}_{2} \mathrm{Cl}_{2}$ (1.13 mL, $2.26 \mathrm{mmol}, 3$ equiv) was added to a stirred solution of acid $12(150 \mathrm{mg}, 0.749 \mathrm{mmol})$ in anhydrous benzene $(2 \mathrm{~mL})$ under nitrogen. The mixture was stirred at $\mathrm{rt}$ for $2 \mathrm{~h}$, then an additional amount of the $2 \mathrm{M}$ solution of oxalyl chloride in $\mathrm{CH}_{2} \mathrm{Cl}_{2}(1.13 \mathrm{~mL})$ was added and the stirring was continued for $3 \mathrm{~h}$. The reaction mixture was diluted with benzene and washed with a saturated aqueous solution of $\mathrm{NaHCO}_{3}$ and brine, dried over anhydrous $\mathrm{Na}_{2} \mathrm{SO}_{4}$, and concentrated under vacuum to give the corresponding acid chloride (142 mg). This acid chloride was dissolved in anhydrous THF $(3 \mathrm{~mL})$ under nitrogen and the solution cooled to $0{ }^{\circ} \mathrm{C}$. $\mathrm{Et}_{3} \mathrm{~N}$ ( $272 \mu \mathrm{L}, 1.95 \mathrm{mmol}, 3$ equiv) was added dropwise, followed by the dropwise addition of a solution of aniline 4 (549 mg, $2.05 \mathrm{mmol}, 1.05$ equiv) in THF ( $1 \mathrm{~mL}$ ). The reaction mixture was stirred at $0{ }^{\circ} \mathrm{C}$ for $1 \mathrm{~h}$ and then at rt overnight. Then, it was diluted with benzene, washed with water and brine, and dried over anhydrous $\mathrm{MgSO}_{4}$. Chromatography of the residue that was left after evaporation of the solvent under vacuum, using a mixture of hexane/EtOAc (from 100:0 to $80: 20)$ as eluent, afforded amide $13(286.7 \mathrm{mg}, 85 \%$ for the two steps) as an oil.

Synthesis of $\mathbf{N}$-(4-(benzyloxy)-2,3-dichlorophenyl)-1-methyl4-oxocyclohexanecarboxamide (14). $1 \mathrm{M}$ hydrochloric acid $(2.5 \mathrm{~mL})$ was added to a solution of ketal $13(267.1 \mathrm{mg}, 0.593$ $\mathrm{mmol})$ in THF $(4 \mathrm{~mL})$ and the mixture stirred at $60{ }^{\circ} \mathrm{C}$ for $2 \mathrm{~h}$. The reaction mixture was cooled down to $\mathrm{rt}$ and diluted with $\mathrm{Et}_{2} \mathrm{O}$, washed with brine, dried over anhydrous $\mathrm{MgSO}_{4}$, and concentrated at reduced pressure to give a residue that was purified by chromatography, using a hexane/EtOAc from 80:20 to $60: 40$ as eluent, to give ketone 14 (197.6 $\mathrm{mg}, 82 \%)$ as a white solid.

Synthesis of 5-(4-((4-(benzyloxy)-2,3dichlorophenyl)carbamoyl)-4-methylcyclohexylidene)

pentanoic acid (16). A $0.5 \mathrm{M}$ solution of potassium bis(trimethylsilyl)amide in toluene $(4.96 \mathrm{~mL}, 2.48 \mathrm{mmol}, 4$ equiv) was dropwise added to a solution of (4carboxybutyl)triphenylphosphonium bromide (550 mg, 1.24 $\mathrm{mmol})$ in anhydrous THF $(5 \mathrm{~mL})$ at $0{ }^{\circ} \mathrm{C}$ under nitrogen. The resulting orange mixture was stirred for $15 \mathrm{~min}$ at this temperature before a solution of ketone $14(251.8 \mathrm{mg}, 0.620$ $\mathrm{mmol})$ in hexamethylphosphorotriamide $(2.5 \mathrm{~mL})$ was added dropwise. The mixture was stirred for $1.5 \mathrm{~h}$ and then poured into water, cooled to $0{ }^{\circ} \mathrm{C}$, acidified with $1 \mathrm{M}$ hydrochloric acid to $\mathrm{pH} \mathrm{2}$, and extracted with EtOAc. The combined organic layers were washed with brine, dried over anhydrous $\mathrm{Na}_{2} \mathrm{SO}_{4}$, and concentrated under vacuum. Chromatographic purification, using hexane/EtOAc 7:3 as eluent, afforded 16 (213 $\mathrm{mg}, 70 \%$ ) as a semisolid.

Synthesis of 5-(4-((2,3-dichloro-4-hydroxyphenyl)carbamoyl)4-methylcyclohexylidene) pentanoic acid (hapten FHd). A $1 \mathrm{M}$ solution of $\mathrm{BCl}_{3}$ in $\mathrm{CH}_{2} \mathrm{Cl}_{2}(420 \mu \mathrm{L}, 0.420 \mathrm{mmol}, 2.1$ equiv) was dropwise added during $5 \mathrm{~min}$ to a solution of benzyl ether 16 (100 mg, $0.200 \mathrm{mmol}$ ) and pentamethylbenzene $(90.7 \mathrm{mg}$, $0.600 \mathrm{mmol}, 3$ equiv) in anhydrous $\mathrm{CH}_{2} \mathrm{Cl}_{2}(3.2 \mathrm{~mL})$ at $-78^{\circ} \mathrm{C}$ under nitrogen atmosphere. The reaction mixture was stirred 
at the same temperature for $10 \mathrm{~min}$ and then quenched by the addition of a 4:1 mixture of THF and an aqueous solution of $\mathrm{NH}_{4} \mathrm{Cl}(10 \mathrm{~mL})$. The mixture was extracted with ethyl ether and the combined ethereal layers were washed with brine and dried over anhydrous $\mathrm{MgSO}_{4}$. Chromatographic purification of the residue that was left after evaporation of the solvent, using $\mathrm{CHCl}_{3} / \mathrm{MeOH}$ 95:5 as eluent, afforded hapten FHd (78 $\mathrm{mg}, 95 \%)$ as a colourless thick oil. IR $v_{\max }\left(\mathrm{cm}^{-1}\right)(\mathrm{NaCl}) 3500-$ 2500, 2978, 2847, 1706, 1656, 1498, 1411, 1274, 1181, 946; ${ }^{1} \mathrm{H}$ $\operatorname{NMR}\left(300 \mathrm{MHz}, \mathrm{CDCl}_{3}\right) \delta(\mathrm{ppm}) 7.93(1 \mathrm{H}, \mathrm{d}, J=9 \mathrm{~Hz}, \mathrm{H}-6 \mathrm{Ph})$, $7.76(1 \mathrm{H}, \mathrm{br} \mathrm{s}, \mathrm{NH}), 6.90(1 \mathrm{H}, \mathrm{d}, J=9 \mathrm{~Hz}, \mathrm{H}-5 \mathrm{Ph}), 5.12(1 \mathrm{H}, \mathrm{t}, J=$ $7.5, \mathrm{H}-5), 2.34(3 \mathrm{H}, \mathrm{m}, 1 \mathrm{H}$ Cy, overlapped with $t, J=7.5 \mathrm{~Hz}, \mathrm{H}-$ 2), $2.24-2.06(5 \mathrm{H}, \mathrm{m}, 5 \mathrm{H} \mathrm{Cy}), 2.05(2 \mathrm{H}, \mathrm{dt}, J=7.5,7.5 \mathrm{~Hz}, \mathrm{H}-4)$, $1.68(2 \mathrm{H}$, quint, $J=7.3 \mathrm{~Hz}, \mathrm{H}-3), 1.52(2 \mathrm{H}, \mathrm{m}, 2 \mathrm{H} \mathrm{Cy}), 1.32(3 \mathrm{H}$, s, $\left.\mathrm{CH}_{3}\right) ;{ }^{13} \mathrm{C} \mathrm{NMR}\left(75 \mathrm{MHz}, \mathrm{CDCl}_{3}\right) \delta(\mathrm{ppm}) 179.5(\mathrm{COOH}), 175.9$ (CON), 149.5 (C4-Ph), 138.2 (C1-Cy), 128.4 (C1-Ph), 123.6 (C2$\mathrm{Ph}), 122.3$ (C6-Ph), 121.3 (C-5), 119.1 (C3-Ph), 114.6 (C5-Ph), 44.3 (С4-Сy), 37.0 (С3-Сy), 36.2 (C5-Сy), 33.2 (C2), 32.9 (С2-Сy), 26.4 (C-4), $26.0\left(\mathrm{CH}_{3}\right), 24.8$ (C3), 24.7 (C6-Cy); HRMS (TOF MS ES+) calcd for $\mathrm{C}_{19} \mathrm{H}_{23} \mathrm{Cl}_{2} \mathrm{NO}_{4}[\mathrm{M}+\mathrm{H}]^{+} 400.1077$, found 400.1074 . UV (100 mM sodium phosphate buffer, pH 7.4), $\varepsilon(280 \mathrm{~nm})=$ $3.62 \mathrm{mM}^{-1} \mathrm{~cm}^{-1}$.

Synthesis of 5-(4-((2,3-dichloro-4-hydroxyphenyl)carbamoyl)4-methylcyclohexyl)pentanoic acid (hapten FHh). A mixture of hapten $\mathrm{FHd}(21 \mathrm{mg}, 0.052 \mathrm{mmol})$ and $5 \%$ Rhodium on alumina $(11 \mathrm{mg})$ in dry EtOAc $(1.5 \mathrm{~mL})$ was stirred under hydrogen $(55$ psi) at $\mathrm{rt}$ for $6 \mathrm{~h}$, after which the black suspension was filtered through a short pad of silica gel, using EtOAc as eluent, to afford the hapten FHh $(20 \mathrm{mg}, 95 \%)$ as an approximately 60:40 mixture of epimers at the newly generated tertiary carbon atom. IR $v_{\max }\left(\mathrm{cm}^{-1}\right)(\mathrm{KBr}) 3500-2500,3415,3322,2929,2853$, $1700,1651,1514,1411,1285,941,815 ;{ }^{1} \mathrm{H}$ NMR $(300 \mathrm{MHz}$, $\mathrm{CDCl}_{3}$ ) (only signals of the major epimer are given) $\delta(\mathrm{ppm})$ $7.97(1 \mathrm{H}, \mathrm{d}, J=9.1 \mathrm{~Hz}, \mathrm{H}-6 \mathrm{Ph}), 7.75(1 \mathrm{H}, \mathrm{br} \mathrm{s}, \mathrm{NH}), 6.91(1 \mathrm{H}, \mathrm{d}$, $J=9.1 \mathrm{~Hz}, \mathrm{H}-5 \mathrm{Ph}), 2.33(2 \mathrm{H}, t, J=7.4 \mathrm{~Hz}, \mathrm{H}-2), 2.21(2 \mathrm{H}, \mathrm{m}, \mathrm{H}-$ $3 / \mathrm{H}-5 \mathrm{Cy}), 1.80-1.53(6 \mathrm{H}, \mathrm{m}, \mathrm{H}-3, \mathrm{H}-5$ and $2 \mathrm{H} \mathrm{Cy}), 1.38-1.07$ (7H, m, C-4, 5H Cy), $1.25\left(3 \mathrm{H}, \mathrm{s}, \mathrm{CH}_{3}\right) ;{ }^{13} \mathrm{C} \mathrm{NMR}\left(75 \mathrm{MHz}, \mathrm{CDCl}_{3}\right)$ (only signals of the major epimer are given) $\delta(\mathrm{ppm}) 179.4$ (COOH), 175.6 (CON), 149.4 (C4-Ph), 128.6 (C1-Ph), 123.2 (C2Ph), 122.1 (C6-Ph), 119.0 (C3-Ph), 114.6 (C5-Ph), 44.5 (C4-Cy), 36.8 (C1-Cy), 36.2 (C3/C5-Cy), 33.9 (C2), 33.7 (C2/C6-Cy), 30.0 (C5), $29.4\left(\mathrm{CH}_{3}\right), 26.2$ (C4), 24.8 (C3). HRMS (TOF MS ES-) calcd for $\mathrm{C}_{19} \mathrm{H}_{24} \mathrm{Cl}_{2} \mathrm{NO}_{4}[\mathrm{M}-\mathrm{H}]$ ] 400.1088, found 400.1091. UV (100 $\mathrm{mM}$ sodium phosphate buffer, $\mathrm{pH} 7.4), \varepsilon(280 \mathrm{~nm})=1.66$ $\mathrm{mM}^{-1} \mathrm{~cm}^{-1}$.

\section{Hapten activation and bioconjugation}

The three synthetic haptens were activated by formation of the corresponding $N$-hydroxysuccinimidyl ester using $N, N^{\prime}$ disuccinimidyl carbonate and $\mathrm{Et}_{3} \mathrm{~N}$ in dry acetonitrile as previously described. ${ }^{25}$ Confirmation of structure and purity of these active esters was obtained by ${ }^{1} \mathrm{H}$ NMR spectroscopic analysis. A more detailed description of the activation reaction and copies of the original spectra are included in the ESI. ${ }^{+}$

Conjugation of haptens to BSA, OVA, and HRP was carried out as previously described. ${ }^{25} \mathrm{BSA}$ conjugates were employed for immunization, OVA conjugates for hybridoma screening assays, and HRP tracers for immunoassay development. Matrix-Assisted Laser Desorption Ionization Time-of-Flight Mass Spectrometry (MALDI-TOF) was performed with a 5800 MALDI-TOF/TOF (ABSciex, Framingham, MA, USA) in positive linear mode ( 1500 shots every position) in a mass range of $15000-130000 \mathrm{~m} / \mathrm{z}$. Every sample was calibrated by close external calibration with a BSA, OVA, or HRP spectrum. The corresponding MALDI spectra are supplied in the ESI. ${ }^{+}$

\section{Monoclonal antibody generation}

Animal manipulation was carried out in compliance with the laws and guidelines of the Spanish Ministry of Agriculture, Food, and Environment, and approved by the Ethics Committee of the University of Valencia (permit number A1248961469416). Immunogen preparation and mouse immunization were performed according to regular procedures as previously published. ${ }^{26}$ Hybridomas were generated, selected, and cloned as described elsewhere. ${ }^{27}$ For details see the ESI. ${ }^{+}$Immunoglobulins were purified from late stationary phase culture supernatants by ammonium sulphate precipitation and protein $\mathrm{G}$ affinity chromatography.

\section{Competitive ELISA}

Ninety-six-well ELISA plates were coated with $100 \mu \mathrm{L}$ per well of a particular antibody solution in $50 \mathrm{mM}$ carbonatebicarbonate buffer, $\mathrm{pH}$ 9.6, and plates were incubated overnight at rt. Coated plates were washed four times with $150 \mathrm{mM} \mathrm{NaCl}$ containing $0.05 \%(\mathrm{v} / \mathrm{v})$ Tween 20 and received, sequentially, $50 \mu \mathrm{L}$ per well of analyte standard solution in PBS (10 mM sodium phosphate buffer, pH 7.4, with $140 \mathrm{mM} \mathrm{NaCl}$ ) plus $50 \mu \mathrm{L}$ per well of enzyme tracer solution in PBST (PBS containing $0.05 \%(\mathrm{v} / \mathrm{v})$ Tween 20$)$. The immunological reaction took place during $1 \mathrm{~h}$ at $\mathrm{rt}$, and then plates were washed as described before. Finally, retained peroxidase activity was determined by adding $100 \mu \mathrm{L}$ per well of freshly prepared $2 \mathrm{~g}$ $\mathrm{L}^{-1} \mathrm{o}$-phenylenediamine solution containing $0.012 \%(\mathrm{v} / \mathrm{v}) \mathrm{H}_{2} \mathrm{O}_{2}$ in $25 \mathrm{mM}$ citrate and $62 \mathrm{mM}$ sodium phosphate buffer, $\mathrm{pH} 5.4$. The enzymatic reaction was stopped after $10 \mathrm{~min}$ at $\mathrm{rt}$ with $100 \mu \mathrm{L}$ per well of $1 \mathrm{M}$ sulfuric acid. The absorbance was immediately read at $492 \mathrm{~nm}$ with a reference wavelength at $650 \mathrm{~nm}$.

Eight-point standard curves were prepared from a $2 \mu \mathrm{g} \mathrm{L}^{-1}$ fenhexamid solution by four-fold serial dilution in PBS, including a blank with no analyte. Experimental values were fitted to a four-parameter logistic equation using the SigmaPlot software package from SPSS Inc. (Chicago, IL, USA). Assay sensitivity was defined as the concentration of analyte at the inflection point of the fitted sigmoidal curve, typically corresponding to a $50 \%$ reduction $\left(\mathrm{IC}_{50}\right)$ of the maximum absorbance $\left(A_{\max }\right)$ if the background signal approaches to zero. Deming regression from the SigmaPlot v.12.0 software was applied for method validation.

\section{Solvent and buffer studies}

Solvent effects over the proposed immunoassay were evaluated using fenhexamid standard curves that had been prepared in the presence of ethanol or acetonitrile at different 
concentrations (from 0.5 to $10 \%(\mathrm{v} / \mathrm{v}$ ) in Milli-Q water). Then, the corresponding immunoreagent solution was prepared in $20 \mathrm{mM}$ sodium phosphate buffer, $\mathrm{pH} 7.4$, containing $280 \mathrm{mM}$ $\mathrm{NaCl}$ and $0.05 \%(\mathrm{v} / \mathrm{v})$ Tween 20 in order to complete the immunoassay. The influence of buffer $\mathrm{pH}$ over the inhibition curve of the CELISA was evaluated using buffers with $\mathrm{pH}$ values between 5.5 and 9.5, which were prepared as reported elsewhere. $^{25}$

\section{Sample treatment}

Tomato and cucumber plants were grown in a greenhouse and treated with Teldor - a wettable powder containing $50 \%(\mathrm{w} / \mathrm{w})$ fenhexamid - following the manufacturer's instructions (http://www.cropscience.bayer.com/). After the application of the commercial product, fruits were collected at different times (from 1 to 14 days) in order to obtain samples with different contents of fungicide, and they were short-term stored at $4{ }^{\circ} \mathrm{C}$. Then, samples were chopped, homogenized using a blender, and stored in polypropylene tubes at $-20^{\circ} \mathrm{C}$ until analysis.

QUEChERS method was employed for the extraction and purification of fenhexamid residues from vegetables. ${ }^{2}$ Five grams of chopped vegetable plus $50 \mu \mathrm{L}$ of internal standard (TPP, $50 \mathrm{mg} \mathrm{L}^{-1}$ ) were introduced in a $50 \mathrm{~mL}$ polypropylene centrifuge tube containing $0.5 \mathrm{~g}$ of sodium acetate and $2 \mathrm{~g}$ of anhydrous magnesium sulphate. Sample was then extracted with $5 \mathrm{~mL}$ of $1 \%(\mathrm{v} / \mathrm{v})$ acetic acid in acetonitrile by vortexing 1 $\mathrm{min}$, and centrifuged for $5 \mathrm{~min}$ at $2200 \times \mathrm{g}$. Then, $1 \mathrm{~mL}$ of extract was introduced into a $2 \mathrm{~mL}$ polypropylene centrifuge tube containing $50 \mathrm{mg}$ of PSA and $150 \mathrm{mg}$ of anhydrous magnesium sulphate, vortexed during $1 \mathrm{~min}$, and centrifuged for $5 \mathrm{~min}$ at $2200 \times \mathrm{g}$. Finally, the purified extract was filtered through a $0.22 \mu \mathrm{m}$ Teflon filter and analysed by the optimized cELISA and also by a reference chromatographic procedure.

\section{Chromatographic analysis}

Ultra-performance liquid chromatography coupled to a triple quadrupole mass spectrometer was selected as reference methodology in order to obtain maximum sensitivity and selectivity for the analysis of fenhexamid residues. Chromatography was performed with a Waters Acquity UPLC system (Milford, MA, USA) equipped with a binary solvent delivery system, an autosampler, and a BEH C18 (1.7 $\mu \mathrm{m}, 2.1 \times$ $50 \mathrm{~mm}$ ) column. The injection volume was set at $5 \mu \mathrm{L}$ and the mobile phase consisted of $0.5 \%(\mathrm{v} / \mathrm{v})$ formic acid in water $(\mathrm{A})$ and acetonitrile (B). The gradient started at $30 \%$ of B, it was linearly increased to $85 \%$ in $3.4 \mathrm{~min}$, and a second ramp to $98 \%$ of $B$ in $1.7 \mathrm{~min}$ at a flow rate of $350 \mu \mathrm{L} \mathrm{min}{ }^{-1}$. The obtained retention times using aforementioned conditions were 3.18 and $3.85 \mathrm{~min}$ for fenhexamid and TPP, respectively. Tandem mass acquisitions were performed in a Waters Acquity triple quadrupole mass spectrometry detector, equipped with a Z-spray electrospray ionization source, with $3.5 \mathrm{kV}$ as capillary voltage, $120{ }^{\circ} \mathrm{C}$ as source temperature, and $300{ }^{\circ} \mathrm{C}$ as desolvation temperature. The employed parameters were: $\mathrm{ESI}+$, parent ion $302 \mathrm{~m} / \mathrm{z}$, daughter ions 97 and $55 \mathrm{~m} / \mathrm{z}, 20 \mathrm{eV}$ collision energy, and $35 \mathrm{~V}$ cone energy for fenhexamid; and
ESI+, parent ion $328 \mathrm{~m} / \mathrm{z}$, daughter ions 77 and $152 \mathrm{~m} / \mathrm{z}, 30 \mathrm{eV}$ collision energy, and $25 \mathrm{~V}$ cone energy for TPP.

\section{Results and discussion}

\section{Hapten design}

The fenhexamid molecule is constituted by a dichlorophenolic moiety - electronically rich, polar, and relatively hydrophilic and a 1-methylcyclohexane group - apolar and lipophilic attached via an amide bridge. In previous studies, ${ }^{19}$ we have obtained antibodies to fenhexamid using, as immunogen, a conjugate between BSA and hapten FHo (Fig. 1), which held the hydrocarbon spacer arm at the phenolic oxygen atom via a $\mathrm{C}-\mathrm{O}-\mathrm{C}$ ether linkage. The use of this immunogenic hapten resulted in the generation of specific antibodies against fenhexamid, in which, presumably, the distal apolar part of the fenhexamid skeleton, i.e., the 1-methylcyclohexane moiety, must represent a key recognition element, and Van der Waals forces and hydrophobic interactions at the binding site make, most likely, a very substantial contribution to the binding energy.

For the present study, new haptens were designed in order to evaluate the immunizing activity and the properties of the generated antibodies when alternative derivatization positions were used (Fig. 1). In hapten $\mathrm{FHm}$, the carboxylate-containing side chain that constituted the spacer arm was placed at a central position of the fenhexamid molecule, by the formal replacement of a $\mathrm{C}-\mathrm{H}$ methyl bond by a $\mathrm{C}-\mathrm{C}$ bond, whereas in hapten $\mathrm{FH} h$, the chain was located at the farthest possible end of the polar part of the molecule, the C-4 position of the cyclohexane ring, also through a $\mathrm{C}-\mathrm{C}$ linkage. No major modification of the electronic and conformational properties of the fenhexamid framework occurred in these haptens, given the nature of the linkage of the side chain and the tethering sites. In both cases, display of the main antigenic determinant of the fenhexamid molecule - the dichlorophenolic moiety was theoretically maximized. This antigen presentation mode was complementary to that of hapten $\mathrm{FHo}$. In principle, the location of the linker in the newly designed haptens should favour the interaction with the distal aromatic and most substituted part of the fenhexamid framework, and could allow the generation of antibody binding sites in which the bimolecular interaction is strongly stabilized by additional forces, such as hydrogen bonding and electrostatic or $\pi$ staking interactions, thus increasing the antibody affinity. Additionally to the above mentioned haptens, hapten $\mathrm{FHd}-$ which was a precursor of the synthesis of hapten $\mathrm{FH} h$ - was also included in this study. In this hapten, the linker was joined at the $\mathrm{C}-4$ position of the cyclohexane ring through a rigid $\mathrm{C}=\mathrm{C}$ double bond which limited the conformational flexibility of both the linker chain and the cyclohexane ring (Fig. 1).

\section{Hapten synthesis}

The common fenhexamid framework of the designed haptens was constructed following a single strategy, i.e., the initial preparation of a conveniently substituted cyclohexane 
carboxylic acid which was coupled with the aminodichlorophenolic moiety through an amidation reaction. The synthesis of hapten $\mathrm{FHm}$ was initiated with the alkylation reaction of the lithium enolate derived from carboxylic acid 1 with allyl bromide to give allyl derivative 2 (Fig. 2). Condensation of this - through the corresponding acyl chloride derivative $\mathbf{3}$ - with the aniline $\mathbf{4}$ led to amide $\mathbf{5}$, which possessed the complete fenhexamid framework and an allyl double bond that was used in the subsequent steps to complete the elaboration of the hydrocarbon chain linker. Thus, microwave assisted cross-metathesis reaction of the double bond of 5 with methyl 4-pentenoate (6), catalysed by a ruthenium-carbene complex (Grubbs 2 nd generation catalyst), followed by catalytic hydrogenation of the double bond and concomitant hydrogenolysis of the benzyl ether moiety of 7 afforded the methyl ester $\mathbf{8}$, whose hydrolysis under standard basic conditions completed the synthesis of hapten $\mathrm{FHm}$. The synthesis of this hapten from readily available carboxylic acid $\mathbf{1}$ involved six synthetic steps with an overall yield of about $30 \%$.

The synthesis of haptens $\mathrm{FHd}$ and $\mathrm{FH} h$ started from ethyl keto-carboxylate 9, which, after protection of the ketone carbonyl group as the corresponding ethylene ketal, was methylated through the corresponding lithium enolate to give 11 (Fig. 3). Completion of the fenhexamid framework was readily achieved through basic hydrolysis of the ester moiety followed by transformation of the obtained acid $\mathbf{1 2}$ to the corresponding acyl chloride and reaction of this with the aniline 4. Acid catalysed hydrolysis of the ethylene ketal group of 13, followed by introduction of the hydrocarbon spacer arm by means of a Wittig olefination reaction, afforded compound 16, which was selectively debenzylated under very mild conditions to give hapten $\mathrm{FH} d$. Catalytic hydrogenation of this, using rhodium over aluminum oxide as catalyst to avoid hydrogenolysis of the $\mathrm{C}-\mathrm{Cl}$ bond, completed the synthesis of hapten $\mathrm{FH} h$, which was obtained as a 60:40 mixture of epimers at the newly generated stereogenic centre. Both epimers could not be separated by the usual chromatographic purification techniques and the mixture was used as such in the preparation of the corresponding protein conjugates. The synthesis of haptens $\mathrm{FHd}$ and $\mathrm{FH} h$ from starting ketocarboxylic ester 9 required seven and eight synthetic steps, with a global yield of $31 \%$ and $30 \%$, respectively.

\section{Bioconjugate evaluation}

The purified active esters of the synthetic haptens were used for covalent coupling to the carrier proteins. Final hapten-toprotein molar ratios (MR) were determined by MALDITOF/MS (Fig. S1), and also by differential absorbance at 280 $\mathrm{nm}$ considering that the extinction coefficients of the hapten and the protein remained unaltered after conjugation. Determinations by both methods were generally comparable (Table 1), except for the HRP conjugates whose MR were inconsistent by UV analysis since only 3 lysine residues of this enzyme are available for conjugation. ${ }^{28}$ In general, the efficiency of the conjugation reaction to BSA and OVA was higher for the conjugates prepared in the present study haptens $\mathrm{FHm}, \mathrm{FHd}$, and $\mathrm{FH} h$ - by using the purified active ester; as compared to the corresponding conjugates of hapten FHo from a previous study ${ }^{19}$ in which the one-pot reaction strategy was followed for hapten coupling. Consequently, lower amounts of hapten were required when the purified active ester was used. Moreover, the final MR could be finely tuned as exemplified by the low hapten densities of the novel OVA conjugates.

\begin{tabular}{lccc}
\hline Table 1 Hapten-to-protein & \multicolumn{3}{c}{ molar ratio of the prepared conjugates } \\
\hline Conjugate & MR ${ }^{a}$ & MALDI & UV \\
\hline BSA-FHm & 30 & 13.4 & 15 \\
BSA-FHd & 30 & 24.0 & 12 \\
BSA-FH $h$ & 30 & 19.8 & 23 \\
BSA-FHo & 74 & 20.0 & 20 \\
OVA-FHm & 3 & 0.9 & 3 \\
OVA-FHd & 3 & 2.2 & 4 \\
OVA-FH $h$ & 3 & 1.6 & 2 \\
OVA-FHo & 13 & 7.0 & 10 \\
HRP-FHm & 10 & 0.7 & 6 \\
HRP-FHd & 10 & 1.4 & 3 \\
HRP-FH $h$ & 10 & 1.2 & 4 \\
HRP-FHo & 18 & 2.0 & 2 \\
a Hapten-to-protein molar ratio in the coupling mixture. & \\
\hline
\end{tabular}

\section{Immunizing activity of haptens}

Mice were immunized with the BSA conjugate of haptens $\mathrm{FHm}$, $\mathrm{FH} d$, and $\mathrm{FH} h$, and novel monoclonal antibodies were raised. All of these immunoglobulins were of the $\operatorname{lgG}_{1}$ isotype and contained a $\mathrm{k}$ light chain. In a previous study, monoclonal antibodies had been generated from hapten $\mathrm{FHo}^{19}$ The complete collection of monoclonal antibodies to fenhexamid including those produced earlier - was evaluated by checkerboard direct cELISA using the corresponding homologous tracer (Table 2). We found that monoclonal antibodies with very low $\mathrm{IC}_{50}$ values (around or below $0.1 \mathrm{nM}$ ) could be obtained from conjugates of the three novel haptens. The position of the linker probably determined that the affinity of the novel antibodies was higher than that of the antibodies

Table 2 Monoclonal antibody characterization $(n=3)^{\text {a }}$

\begin{tabular}{lrcc}
\hline $\mathrm{mAb}$ & {$[\mathrm{T}]^{\mathrm{b}}$} & $\mathrm{A}_{\max }$ & $\mathrm{IC}_{50}{ }^{\mathrm{c}}$ \\
\hline $\mathrm{FH} h \# 15$ & 30 & 1.19 & 0.04 \\
$\mathrm{FH} h \# 122$ & 100 & 0.92 & 0.08 \\
$\mathrm{FH} h \# 130$ & 30 & 0.85 & 0.08 \\
$\mathrm{FHd \# 19}$ & 3 & 0.82 & 0.60 \\
$\mathrm{FHd \# 132}$ & 30 & 1.27 & 0.08 \\
$\mathrm{FHd \# 139}$ & 10 & 1.56 & 0.12 \\
$\mathrm{FH} m \# 110$ & 30 & 1.63 & 0.14 \\
$\mathrm{FH} m \# 113$ & 10 & 0.86 & 0.05 \\
FHm\#114 & 100 & 1.02 & 0.02 \\
FHo\#22 & 30 & 1.92 & 0.93 \\
FHo\#26 & 10 & 1.29 & 0.66 \\
FHo\#27 & 10 & 1.55 & 0.69
\end{tabular}

${ }^{\mathrm{a}}$ Antibody coating concentration was $1000 \mathrm{ng} \mathrm{mL}^{-1}$. ${ }^{\mathrm{b}}$ Tracer concentration in $\mathrm{ng}$ $\mathrm{mL}^{-1}$. ${ }^{\mathrm{C}}$ Values are in $\mathrm{nM}$ units. 


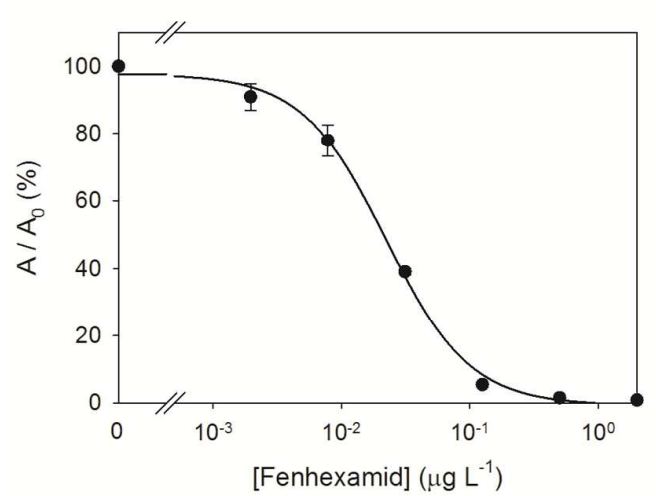

Fig. 4 Standard inhibition curve for the proposed cELISA. Plates were coated with a $1000 \mathrm{ng} \mathrm{mL}^{-1} \mathrm{FHm \# 114}$ antibody solution and tracer HRP-FH $h$ was employed at 30 $\mathrm{ng} \mathrm{mL} \mathrm{L}^{-1}$. Results are the mean of five independent experiments. Curve parameters were: $A_{\max }=98 \pm 3 \%$, slope $=-1.32 \pm 0.09, \mathrm{IC}_{50}=0.022 \pm 0.002 \mu \mathrm{g} \mathrm{L}^{-1}$, lower asymptote $=0 \pm 2 \%$, and $R^{2} 0.998$.

generated previously from hapten FHo. Interestingly, the outstanding affinity values of antibodies that were raised with haptens $\mathrm{FH} h$ and $\mathrm{FH} d$ was independent of the double bond at the linker tethering site. More surprisingly, extraordinary affinities were also displayed by antibodies generated from hapten $\mathrm{FHm}$, with a central tethering site closer to the dichlorophenolic moiety. All of the monoclonal antibodies were specific of fenhexamid. Twenty-two fungicides (pyraclostrobin, kresoxim-methyl, trifloxystrobin, azoxystrobin, dimoxystrobin, fluoxastrobin, metominostrobin, picoxystrobin, boscalid, captan, cyprodinil, mepanipyrim, pyrimethanil, procymidone, tolylfluanid, cyazofamid, tebuconazole, fenamidone, fludioxonil, vinclozolin, imidacloprid, and benzanilide) were evaluated as competitors. Calibration curves were prepared up to $10 \mu \mathrm{M}$ for each compound in PBS and no inhibition was observed.

\section{Immunoassay selection and characterization}

The antibody-tracer combination providing the highest sensitivity with moderate immunoreagent consumption for a satisfactory signal at zero dose of analyte, was selected by checkerboard cELISA using homologous and heterologous enzyme tracers (Table S1). On these bases, antibody FHm\#114 and the heterologous tracer HRP-FH $h$ were selected for further immunoassay development. The standard inhibition curve of the proposed cELISA is shown in Fig. 4. The $A_{\max }$ value of the sigmoidal curve was 1.3 absorbance units, the slope was -1.32 , the $\mathrm{IC}_{50}$ value was $20 \mathrm{ng} \mathrm{L^{-1 }}$, and the background signal was close to zero. Moreover, the limit of detection (LOD), estimated as the fenhexamid concentration that provided a $10 \%$ reduction of the $A_{\max }$, was $4 \mathrm{ng} \mathrm{L}^{-1}$. Precision of the inhibition curve was determined as the relative standard deviation of $A_{\max }$, slope, and $\mathrm{IC}_{50}$ values in repetitive experiments (Table S2). Both for intra-day and for inter-day determinations, precision results were lower than $10 \%$.

\section{Influence of solvents and buffer $\mathrm{pH}$}

The influence of acetonitrile and ethanol over the $A_{\max }$ and $I C_{50}$ values of the standard curve was assessed in order to study the tolerance to solvents of the studied cELISA. Acetonitrile was evaluated because it is employed in the QuEChERS methodology, whereas ethanol is present in alcoholic drinks and in fermented food samples. It was found that both solvents were quite well tolerated (Fig. 5). Acceptable variations of $A_{\max }$ values (between $\pm 20 \%$ ) were observed with $10 \%$ and $5 \%$ acetonitrile and ethanol, respectively. However, tolerable variations of the $\mathrm{IC}_{50}$ value only occurred at solvent concentrations below $2 \%$. Besides, the effect of buffer $\mathrm{pH}$ over the main inhibition curve parameters of the proposed cELISA was investigated. A strong dependence of $A_{\max }$ and $I C_{50}$ values with the buffer $\mathrm{pH}$ was evidenced, which was consistent with the acid dissociation constant of fenhexamid ( $p K a=7.3$ ).

\section{Determination of fenhexamid residues in vegetables}

Tomato and cucumber were selected as model samples in order to study the interferences of vegetable matrices over the inhibition curve parameters of the developed cELISA. Matrix effects were evaluated using fenhexamid-free samples (measured by UPLC-MS/MS), which were extracted by the QuEChERS procedure and then diluted with Milli-Q water $(1 / 5$, $1 / 15,1 / 50,1 / 150$, and 1/500). A fenhexamid standard curve was prepared with every diluted sample extract, and assayed in coated microplates and with the corresponding tracer solution in $20 \mathrm{mM}$ sodium phosphate buffer, $\mathrm{pH}$ 7.4, containing $280 \mathrm{mM} \mathrm{NaCl}$ and $0.05 \%(\mathrm{v} / \mathrm{v}$ ) Tween 20. Similar matrix effects were observed with both vegetables (Fig. S2).

Recovery studies were performed using the same analytefree samples. Vegetables were processed as described in the
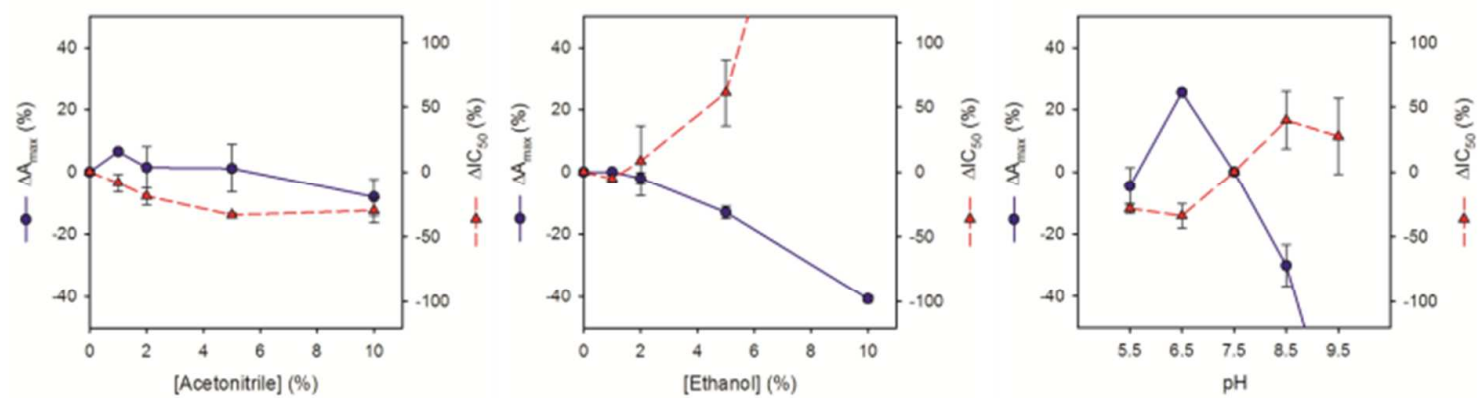

Fig. 5 Influence of acetonitrile, ethanol, and buffer $\mathrm{pH}$ changes over the $\mathrm{A}_{\max }$ and $\mathrm{IC}_{50}$ values of the studied cELISA. 
Table 3 Recoveries from spiked tomato and cucumber samples

\begin{tabular}{|c|c|c|c|}
\hline \multirow{2}{*}{$\begin{array}{l}{[\mathrm{FH}]^{\mathrm{a}}} \\
\left(\mu \mathrm{g} \mathrm{kg}^{-1}\right)\end{array}$} & \multirow[b]{2}{*}{ Dilution } & \multicolumn{2}{|c|}{ Recovery $(\% \pm s, n=3)$} \\
\hline & & Tomato & Cucumber \\
\hline 0.5 & $1 / 50$ & $95 \pm 5$ & $95 \pm 6$ \\
\hline 1 & $1 / 50$ & $89 \pm 20$ & $100 \pm 6$ \\
\hline 5 & $1 / 50$ & $83 \pm 7$ & $105 \pm 13$ \\
\hline 10 & $1 / 500$ & $98 \pm 8$ & $87 \pm 8$ \\
\hline 50 & $1 / 500$ & $98 \pm 14$ & $92 \pm 6$ \\
\hline 100 & $1 / 500$ & $90 \pm 11$ & $96 \pm 18$ \\
\hline 500 & $1 / 5000$ & $93 \pm 12$ & $88 \pm 8$ \\
\hline 1000 & $1 / 5000$ & $100 \pm 8$ & $113 \pm 16$ \\
\hline Fenhexam & entration. & & \\
\hline
\end{tabular}

Experimental section, spiked with fenhexamid at different concentrations, and homogenized by vortex mixing. Fortified samples were extracted by QuEChERS and measured by the developed cELISA. Excellent recoveries with RSD lower than $20 \%$ were obtained in both sorts of foodstuff (Table 3 ). From these results, the LOQ - defined as the minimal concentration that is possible to measure with adequate accuracy and precision - could be established at $0.5 \mu \mathrm{g} \mathrm{kg}^{-1}$.

The developed immunoassay was validated by comparison with a reference chromatographic method using in-field treated and blind spiked samples. Tomato and cucumber crops were sprayed with a commercial fenhexamid preparation following good agricultural practices. Vegetables were collected at different moments and homogenized, and the QUEChERS-based extracts were analysed by the developed CELISA and by UPLC-MS/MS. As listed in Table S3, the fenhexamid concentration that was found for in-field treated samples ranged from 28 to $1000 \mu \mathrm{g} \mathrm{kg}^{-1}$ - equal or lower than the EU maximum residue limit (1000 $\mu \mathrm{g} \mathrm{kg}^{-1}$; http://ec.europa.eu/sanco pesticides/). In addition, spiked blind samples were prepared in order to obtain a higher number of positive samples that could be useful for immunoassay validation with a reference method. A total of 8 samples of each foodstuff were spiked by an external operator and analysed (Table S3). For accurate method comparison, Deming regression was employed. Fig. 6 shows the regression

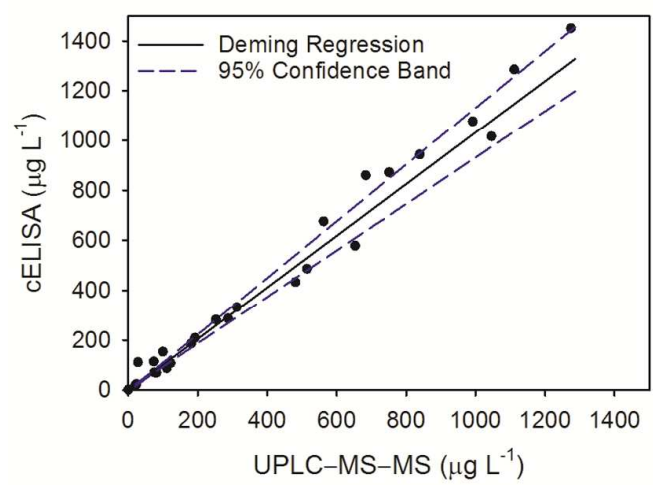

Fig. 6 Deming regression between the developed cELISA and UPLC-MS/MS with $95 \%$ confidence intervals. curve for the developed immunoassay against UPLC-MS/MS with $95 \%$ confidence interval $(\mathrm{Cl})$ bands. The slope was $1.03(\mathrm{Cl}$ from 0.93 to 1.14$)$ and the intercept was -1.5 ( $\mathrm{Cl}$ from -6.9 to 3.9). Therefore, since the slope and intercept values were statistically equal to 1 and 0 , respectively, the immunochemical results and those obtained by UPLC-MS/MS were comparable.

\section{Conclusions}

Accurate hapten design can help to improve antibody binding properties. Particularly, the linker tethering site has been demonstrated as a determinant factor for high-affinity and specific antibody generation. Three new functionalized haptens of fenhexamid have been prepared by total synthesis and protein conjugates were produced. Purification of the active ester for conjugation was shown to increase the coupling efficiency, thus reducing the amount of required hapten. A collection of monoclonal antibodies from these novel haptens was obtained, most of them displaying outstandingly low $\mathrm{IC}_{50}$ values (below $0.1 \mathrm{nM}$ ). Based on one of these monoclonals, a direct immunoassay has been characterized for the determination of fenhexamid residues in vegetables. QuEChERS-based extracts were directly diluted in water and analysed by the developed cELISA, affording excellent results from fortified, in-field treated, and blind spiked tomato and cucumber samples, with a LOQ of $0.5 \mu \mathrm{g}$ $\mathrm{kg}^{-1}$. Moreover, this immunoassay showed excellent trueness, precision, and robustness, and afforded results that were statistically comparable to those of a chromatographic reference procedure. The proposed immunoassay is a straightforward and rapid method that combines high sensitivity, selectivity, and sample throughput for the analysis of fenhexamid in foodstuffs.

\section{Conflicts of interest}

There are no conflicts to declare.

\section{Acknowledgements}

This work was supported by the Spanish Ministerio de Economía y Competitividad (AGL2012-39965-C02 and AGL2015-64488-C2) and cofinanced by European Regional Development Funds. The proteomic analysis was performed at the Proteomics Section of SCSIE of the University of Valencia which belongs to ProteoRed, PRB2-3, and was supported by grant PT17/0019, of the PE I+D+i 2013-2016, and funded by ISCIII and ERDF. Animal manipulation was carried out at the Animal Production Section, also belonging to the SCSIE of the University of Valencia..

\section{Notes and references}

1 B.-W. Krüger, W. Etzel and A. Goehrt, PflanzenschutzNachrichten Bayer, 1999, 52, 119. 
2 AOAC Official Method 2007.01, Pesticide residues in foods by acetonitrile extraction and partitioning with magnesium sulphate gas chromatography/mass spectrometry and liquid chromatography/tandem mass, Association of Analytical Communities (AOAC). http://www.eoma.aoac.org/, 2018 (accessed 23 April 2018).

3 European Standard EN 15662:2008, Foods of plant origin Determination of pesticide residues using GC-MS and/or LC$\mathrm{MS} / \mathrm{MS}$ following acetonitrile extraction/partitioning and clean-up by dispersive SPE-QuEChERS method, European Committee for Standardization. https://standards.cen.eu/dyn/www/f?p=204:110:0::::FSP PR OJECT,FSP ORG ID:27745,6256\&cs=12841E96B34C99F60A6 9E21CCA73C33F0, 2008 (accessed 23 April 2018).

4 C. Lesueur, P. Knittl, M. Gartner, A. Mentler and M. Fuerhacker. Food Control, 2008, 19, 906.

5 S. Walorczyk, D. Drożdżyński and B. Gnusowski, Talanta, 2011, 85, 1856.

6 B. Kmellár, P. Fodor, L. Pareja, C. Ferrer, M. A. MartínezUroz, A. Valverde and A. R. Fernandez-Alba, J. Chromatogr. $A, 2008,1215,37$.

7 B. Gilbert-López, J. F. García-Reyes, A. Lozano, A. R. Fernández-Alba and A. Molina-Díaz, J. Chromatography $A$, 2010, 1217, 6022.

8 R. P. Carneiro, F. A. S. Oliveira, F. D. Madureira, G. Silva, W. R. de Souza and R. Pereira Lopes, Food Control, 2013, 33, 413.

9 C. A. Spinks, G. M. Wyatt, H. A. Lee and M. R. Morgan, Bioconjug. Chem., 1999, 10, 583.

10 N. A. Lee and I. R. Kennedy, J. AOAC Int., 2001, 84, 1393.

11 G. Shan, C. Lipton, S. J. Gee and B. D. Hammock, in Handbook of Residue Analytical Methods for Agrochemicals, ed. Philip W. Lee, John Wiley \& Sons Ltd., Chichester, 2002, pp. 623679.

12 K. Shreder, Methods, 2000, 20, 372.

13 M. P. Marco, S. Gee and B. D. Hammock, Trac-Trend Anal. Chem., 1995, 14, 463.

14 K. Landsteiner, The Specifity of Serological Reactions, Dover Publications, New York, 1962.

15 X. Li, P. Li, Q. Zhang, Y. Li, W. Zhang and X. Ding, Anal. Chem., 2012, 84, 5229.

$16 \mathrm{H}$. Zeng, J. Chen, C. Zhang, X. Huang, Y. Sun, Z. Xu and H. Lei, Anal. Chem., 2016, 88, 3909.

17 C. Suárez-Pantaleón, J. V. Mercader, C. Agulló, A. AbadSomovilla and A. Abad-Fuentes, Org. Biomol. Chem., 2011, 9, 4863.

18 R. López-Moreno, J. V. Mercader, C. Agulló, A. AbadSomovilla and A. Abad-Fuentes, Org. Biomol. Chem., 2013, 11, 7361 .

19 J. V. Mercader and A. Abad-Fuentes, J. Agric. Food Chem., 2009, 57, 5129.

20 F. J. Barrios, B. C. Springer and D. A. Colby, Org. Lett., 2013, 15, 3082 .

21 S. Nicolai, C. Piemontesi and J. Waser, Angew. Chem. Int. Ed., 2011, 50, 4680.

22 R. R. Calvo, S. K. Meegalla, D. J. Parks, W. H. Parsons, S. K. Ballentine, M. L. Lubin, C. Schneider, R. W. Colburn, C. M. Flores and M. R. Player, Bioorg. Med. Chem. Lett., 2012, 22, 1903.

23 S. Zheng, L. Y. R. Santosh, E. David, A. T. Dinkova-Kostova, K. H. Shiavoni, Y. Ren, Y. Zheng, I. Trevino, R. Bumeister, I. Ojima, W. C. Wigley, J. B. Bliska, D. F. Mierke and T. Honda, J. Med. Chem., 2012, 55, 4837

24 E. W. Della and A. M. Knill, Aust. J. Chem., 1994, 47, 1833.

25 F. A. Esteve-Turrillas, J. Parra, A. Abad-Fuentes, C. Agulló, A. Abad-Somovilla and J. V. Mercader, Anal. Chim. Acta, 2010, 682, 93 .
26 C. Suárez-Pantaleón, J. V. Mercader, C. Agulló, A. AbadSomovilla and A. Abad-Fuentes, J. Agric. Food Chem., 2008, 56,11122

27 J. V. Mercader, C. Suárez-Pantaleón, C. Agulló, A. AbadSomovilla and A. Abad-Fuentes, J. Agric. Food Chem., 2008, 56, 7682.

28 G. T. Hermanson, Bioconjugate Techniques, Academic Press, San Diego, 1996. 
1

2

3

4

5

6

7

8

9

10

11

12

13

14

15

16

17

18

19

20

21

22

23

24

25

26

27

28

29

30

31

32

33

34

35

36

37

38

39

40

41

42

43

44

45

46

47

48

49

50

51

52

53

54

55

56

57

58

59

60

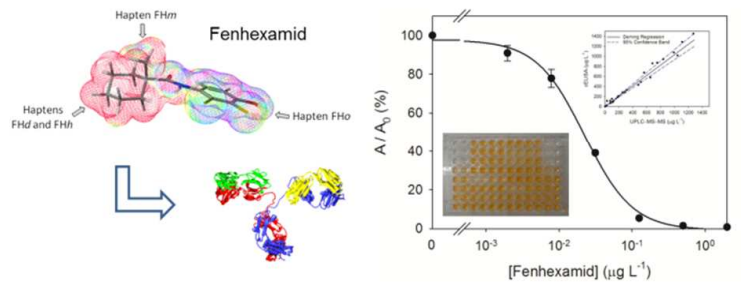

The importance of an optimum hapten design for developing highly sensitive immunoassays has been demonstrated. 


\section{Supplementary Information}

\section{Rationally designed haptens for highly sensitive monoclonal antibody-based immunosensing of fenhexamid}

Francesc A. Esteve-Turrillas, Consuelo Agulló, Josep V. Mercader, A. Abad-Somovilla and A. Abad-Fuentes

General information

Page

Preparation of 4-(benzyloxy)-2,3-dichloroaniline (4)

2

Characterization data of intermediates of the synthesis of hapten $\mathrm{FHm} 3$

Characterization data of intermediates of the synthesis of haptens $\mathrm{FH} d$ and $\mathrm{FH} h \quad 5$

$\begin{array}{ll}\text { Hapten activation and conjugation } & 7\end{array}$

MALDI-TOF spectra of bioconjugates (Figure S1) 8

Monoclonal antibody generation $\quad 8$

$\begin{array}{ll}\text { Checkerboard titration (Table S1) } & 9\end{array}$

$\begin{array}{ll}\text { Precision of the standard curve (Table S2) } & 10\end{array}$

$\begin{array}{ll}\text { Matrix effects (Figure S2) } & 10\end{array}$

Determination of fenhexamid in vegetables by CELISA and UPLC-MS (Table S3) 10

${ }^{1} \mathrm{H}$ NMR spectra of haptens $\mathrm{FHm}, \mathrm{FH} d$ and $\mathrm{FH} h$ and their NHS-esters 11 


\section{General information}

Reactions involving air-sensitive compounds were conducted in oven-dried glassware under a nitrogen atmosphere. Chromatography refers to flash column chromatography and it was carried out with the indicated solvents on silica gel 60 (particle size $0.040-0.063 \mathrm{~mm}$ ). Reactions were monitored with the aid of thin-layer chromatography (TLC) using $0.25 \mathrm{~mm}$ pre-coated silica gel plates. Visualization was carried out with UV light and aqueous ceric ammonium molybdate solution. Melting points were determined using a Kofler hot-stage apparatus or a Büchi melting point apparatus and are uncorrected. NMR spectra were recorded at room temperature on a Bruker AC-300 spectrometer $\left(300.13 \mathrm{MHz}\right.$ for ${ }^{1} \mathrm{H}$ and $75.47 \mathrm{MHz}$ for ${ }^{13} \mathrm{C}$ ). The spectra were referenced to residual solvent protons in ${ }^{1} \mathrm{H}$ NMR spectra (7.26 ppm, 3.58 for THF- $d_{8}$ and 3.31 for $\left.\mathrm{CD}_{3} \mathrm{OD}\right)$ and to solvent carbons in ${ }^{13} \mathrm{C}$ NMR spectra (77.00 ppm and 67.57 for $\mathrm{THF}^{-\mathrm{d}_{8}}$ ). Carbon substitution degrees were established by DEPT pulse sequences. The abbreviation used for NMR data are as follows: $s=$ singlet, $d=$ doublet, $d d d=$ double double doublet, $t=$ triplet, $\mathrm{q}=$ quadruplet, $\mathrm{dt}=$ double triplet, quint = quintuplet, $\mathrm{br}=$ broad, $\mathrm{m}=$ multiplet; $\mathrm{Cy}=\mathrm{cyclohexyl}$ ring, $\mathrm{Ph}=$ phenyl ring, $\mathrm{Bn}=$ aromatic benzyl ring. Infrared (IR) spectra were measured using a Nicolet Avatar 320 FT-IR spectrometer. High resolution mass spectra (HRMS) were recorded by the electrospray (ES) ionization mode using a Q-TOF premier mass spectrometer with an electrospray source (Waters, Manchester, UK).

\section{Preparation of 4-(benzyloxy)-2,3-dichloroaniline (4)}

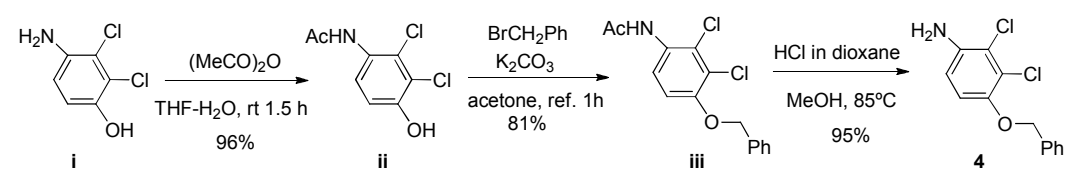

a) Acetic anhydride (589 $\mu \mathrm{L}, 6.24 \mathrm{mmol}, 1.1$ equiv) was dropwise added to a well stirred solution of 4-amino-2,3-dichlorophenol $(1.00 \mathrm{~g}, 5.67 \mathrm{mmol})$ in THF $(10 \mathrm{~mL})$ and $\mathrm{H}_{2} \mathrm{O}(5 \mathrm{~mL})$ at room temperature. The reaction mixture was stirred at this temperature for $1.30 \mathrm{~h}$ and then poured into water and extracted with $\mathrm{Et}_{2} \mathrm{O}$. The combined organic layers were washed with an aqueous saturated solution of $\mathrm{NaHCO}_{3}$ and brine and dried over anhydrous $\mathrm{Na}_{2} \mathrm{SO}_{4}$. Evaporation of the solvent at reduced pressure led to crude acetamide ii (1.199 $\mathrm{mg}, 96 \%)$.

b) Benzyl bromide (1.3 mL, $10.9 \mathrm{mmol}, 2$ equiv) was added to a stirred mixture of the above obtained acetamide and $\mathrm{K}_{2} \mathrm{CO}_{3}(3.766 \mathrm{~g}, 27.28 \mathrm{mmol}, 5$ equiv) in anhydrous acetone (37 $\mathrm{mL}) \mathrm{under}$ nitrogen. The reaction mixture was stirred under reflux for $1 \mathrm{~h}$, allowed to cool to room temperature, filtered through a short plug of celite, washing with acetone, and the filtrate concentrated under reduced pressure. Chromatography of the residue obtained, using hexane-EtOAc mixtures from 100:0 to 
50:50, afforded $\mathrm{N}$-(4-(benzyloxy)-2,3-dichlorophenyl)acetamide iii (1.37 g, 81\%). ${ }^{1} \mathrm{H}$ NMR (300 MHz, $\left.\mathrm{CDCl}_{3}\right) \delta 8.18(1 \mathrm{H}, \mathrm{d}, J=9.3 \mathrm{~Hz}, \mathrm{H}-5 \mathrm{Ph}), 7.43(6 \mathrm{H}, \mathrm{m}, \mathrm{C} 2-6 \mathrm{Bn}$ and $\mathrm{NH}), 6.92(1 \mathrm{H}, \mathrm{d}, J=9.3 \mathrm{~Hz}, \mathrm{H}-6 \mathrm{Ph})$, $5.16\left(2 \mathrm{H}, \mathrm{s}, \mathrm{CH}_{2}\right), 2.23\left(3 \mathrm{H}, \mathrm{s}, \mathrm{CH}_{3}\right)$.

c) A solution of $\mathrm{HCl}$ in dioxane $(4 \mathrm{M}, 12 \mathrm{~mL}, 46 \mathrm{mmol})$ was added to a solution of acetamide iii (942 $\mathrm{mg}, 3.036 \mathrm{mmol})$ in $\mathrm{CH}_{3} \mathrm{OH}(18.9 \mathrm{~mL})$ and the mixture was refluxed under anhydrous conditions for 2.30 h. The reaction mixture was cooled to room temperature, poured into $\mathrm{H}_{2} \mathrm{O}$ and basified to $\mathrm{pH} 9-10$ by the addition of $3 \mathrm{M} \mathrm{NaOH}$. The basic mixture was extracted with $\mathrm{Et}_{2} \mathrm{O}$ and the organic extracts were washed with brine and dried with anhydrous $\mathrm{Na}_{2} \mathrm{SO}_{4}$. Evaporation of the solvent under vacuum left to the solid aniline 4 (745 mg, 95\%) whose ${ }^{1}$ H NMR spectrum (identical with that previously reported in the literature $)^{1}$ showed to be essentially pure and was used without further purification. ${ }^{1} \mathrm{H} N M R(300 \mathrm{MHz}$, $\left.\mathrm{CDCl}_{3}\right) \delta 7.39(5 \mathrm{H}, \mathrm{m}, \mathrm{C} 2-6 \mathrm{Bn}$ ), 6.77 and 6.61 (each $1 \mathrm{H}, \mathrm{AB}$ system, $J=9.0 \mathrm{~Hz}, \mathrm{H}-5$ and $\mathrm{H}-6 \mathrm{Ph}), 5.06(2 \mathrm{H}$, $\left.\mathrm{s}, \mathrm{CH}_{2}\right), 3.91\left(2 \mathrm{H}, \mathrm{br} \mathrm{s}, \mathrm{NH}_{2}\right)$.

\section{Characterization data of intermediates of the synthesis of hapten $\mathrm{FHm}$}

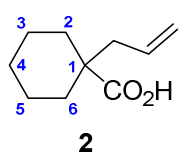

1-Allylcyclohexanecarboxylic acid (2). ${ }^{2} \mathrm{IR} v_{\max } / \mathrm{cm}^{-1}(\mathrm{NaCl}) 2500-3000,1697,1640,1453,1245,917 ;{ }^{1} \mathrm{H}$ NMR $\left(300 \mathrm{MHz} \mathrm{CDCl}_{3}\right) \delta 11.44\left(1 \mathrm{H}, \mathrm{br} \mathrm{s}, \mathrm{CO}_{2} \mathrm{H}\right), 5.75(1 \mathrm{H}, \mathrm{m},=\mathrm{CH}), 5.08$ and $5.03(1 \mathrm{H}$ each, each $\mathrm{m}$, $\left.=\mathrm{CH}_{2}\right), 2.30\left(2 \mathrm{H}, \mathrm{d}, \mathrm{J}=7.5 \mathrm{~Hz}, \mathrm{CH}_{2} \mathrm{CH}=\right), 2.04(2 \mathrm{H}, \mathrm{m}, \mathrm{H}-2 / \mathrm{H}-6 \mathrm{Cy}), 1.59-120(8 \mathrm{H}, \mathrm{m}, 10 \mathrm{CH}-\mathrm{Cy}) ;{ }^{13} \mathrm{C} \mathrm{NMR}(75$ $\left.\mathrm{MHz}, \mathrm{CDCl}_{3}\right) \delta 183.5\left(\mathrm{CO}_{2} \mathrm{H}\right), 133.3(=\mathrm{CH}), 117.9\left(=\mathrm{CH}_{2}\right), 47.1$ (C1-Cy), $44.3\left(\mathrm{CH}_{2}-\mathrm{C}=\right), 33.4(\mathrm{C} 2 / \mathrm{C} 6-\mathrm{Cy}), 25.7$ (C4-Сy), 23.0 (C3/C5-Cy).

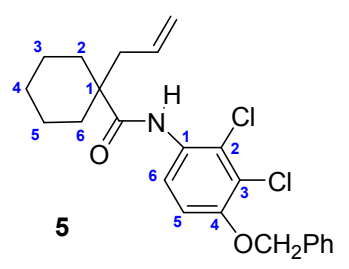

1-Allyl-N-(4-(benzyloxy)-2,3-dichlorophenyl)cyclohexanecarboxamide (5). IR $v_{\max } / \mathrm{cm}^{-1}(\mathrm{NaCl}) 3431$, $3312,3070,2930,2859,1675,1592,1508,1466,1272,1133 ;{ }^{1} \mathrm{H}$ NMR $\left(300 \mathrm{MHz}, \mathrm{CDCl}_{3}\right) \delta 8.20(1 \mathrm{H}, \mathrm{d}, J=$ $9.3 \mathrm{~Hz}, \mathrm{H}-6 \mathrm{Ph}), 7.81(1 \mathrm{H}, \mathrm{br} \mathrm{s}, \mathrm{NH}), 7.45-7.29(5 \mathrm{H}, \mathrm{m}, \mathrm{C} 2-6 \mathrm{Bn}), 6.92(1 \mathrm{H}, \mathrm{d}, J=9.3 \mathrm{~Hz}, \mathrm{H}-5 \mathrm{Ph}), 5.74(1 \mathrm{H}$, $\mathrm{m},=\mathrm{CH}), 5.15\left(2 \mathrm{H}, \mathrm{s}, \mathrm{OCH}_{2}\right), 5.09$ and $5.04\left(1 \mathrm{H}\right.$ each, each $\left.\mathrm{m},=\mathrm{CH}_{2}\right), 2.33\left(2 \mathrm{H}, \mathrm{d}, \mathrm{J}=7.5 \mathrm{~Hz}, \mathrm{CH}_{2} \mathrm{CH}=\right), 2.05$

\footnotetext{
${ }^{1}$ a) Dinsmore, C. J.; Bergman, J. M. Inhibitors of prenyl-protein transferase. PCT Int. Appl. (2001), WO2001060815 A1, 2001-0823. b) Practical Application of the Palladium-catalyzed Amination in Phenylpiperazine Synthesis: An Efficient Synthesis of a Metabolite of the Antipsychotic Agent Aripiprazole. Tetrahedron, 1998, 54, 4811-4818.

${ }^{2}$ Nicolai, Stefano; Piemontesi, Cyril; Waser, Jerome. A Palladium-Catalyzed Aminoalkynylation Strategy towards Bicyclic Heterocycles: Synthesis of ( \pm )-Trachelanthamidine. Angew. Chem. Int. Ed., 2011, 50, 4680-4683.
} 
$(2 \mathrm{H}, \mathrm{m}, \mathrm{H}-2 / \mathrm{H}-6 \mathrm{Cy}), 1.70-1.25$ (8H, m, $8 \mathrm{CH}-\mathrm{Cy}) ;{ }^{13} \mathrm{C} \mathrm{NMR}\left(75 \mathrm{MHz}, \mathrm{CDCl}_{3}\right) \delta 174.2$ (CON), 151.4 (C4-Ph), 136.1 (C1-Bn), 133.1 (=CH), 129.5 (C1-Ph), 128.6 (C3/C5-Bn), 128.1 (C4-Bn), 127.1 (C2/C6-Bn), 123.6 (C2$\mathrm{Ph}), 122.3$ (C3-Ph), 120.1 (C6-Ph), $118.5\left(=\mathrm{CH}_{2}\right), 112.5$ (C5-Ph), $71.4\left(\mathrm{OCH}_{2}\right), 47.8$ (C1-Cy), $44.8\left(\mathrm{CH}_{2}-\mathrm{C}=\right)$, 34.0 (C2/C6-Cy), 25.8 (C4-Cy), 22.8 (C3/C5-Cy); HRMS (TOF MS ES+) calcd for $\mathrm{C}_{23} \mathrm{H}_{26} \mathrm{Cl}_{2} \mathrm{NO}_{2}[\mathrm{M}+\mathrm{H}]^{+}$ 418.1341, found 418.1347 .

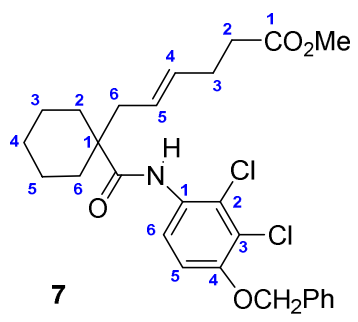

(E)-Methyl 6-(1-((4-(benzyloxy)-2,3-dichlorophenyl)carbamoyl)cyclohexyl) hex-4-enoate (7). IR $v_{\max } / \mathrm{cm}^{-1}(\mathrm{NaCl}) 3432,3310,2929,1737,1679,1594,1510,1470,1272,1026 ;{ }^{1} \mathrm{H}$ NMR $\left(300 \mathrm{MHz}, \mathrm{CDCl}_{3}\right) \delta$ $8.18(1 \mathrm{H}, \mathrm{d}, J=9.3 \mathrm{~Hz}, \mathrm{H}-6 \mathrm{Ph}), 7.79(1 \mathrm{H}, \mathrm{br}, \mathrm{NH}), 7.47-7.32(5 \mathrm{H}, \mathrm{m}, \mathrm{C} 2-6 \mathrm{Bn}), 6.92(1 \mathrm{H}, \mathrm{d}, J=9.3 \mathrm{~Hz}, \mathrm{H}-5$ $\mathrm{Ph}), 5.37(2 \mathrm{H}, \mathrm{m}, \mathrm{H}-4$ and $\mathrm{H}-5), 5.09\left(2 \mathrm{H}, \mathrm{s}, \mathrm{OCH}_{2}\right), 3.55\left(3 \mathrm{H}, \mathrm{s}, \mathrm{CO}_{2} \mathrm{CH}_{3}\right), 2.30(4 \mathrm{H}, \mathrm{m}, \mathrm{H}-2$ and $\mathrm{H}-3), 2.25$ $(2 \mathrm{H}, \mathrm{m}, \mathrm{H}-6), 2.05$ (2H, H-2/H6-Cy), 1.70-1.25 (8H, m, $8 \mathrm{CH}-\mathrm{Cy}) ;{ }^{13} \mathrm{C} \mathrm{NMR}\left(75 \mathrm{MHz}, \mathrm{CDCl}_{3}\right) \delta 174.3$ (CON), $173.4\left(\mathrm{CO}_{2}\right), 151.4$ (C4-Ph), 136.1 (C1-Bn), 132.3 (C4), 129.5 (C1-Ph), 128.6 (C3/C5-Bn), 128.1 (C4-Bn), 127.1 (C2/C6-Bn), 125.8 (C5), 125.2 (C2-Ph), 123.6 (C3-Ph), 120.1 (C6-Ph), 112.4 (C5-Ph), 71.4 (OCH ${ }_{2}$, $51.5\left(\mathrm{OCH}_{3}\right.$ ), 48.0 (C1-Cy), 34.0 (C2/C6-Cy), 33.8 (C2), 27.8 (C3), 25.8 (C4-Cy), 22.8 (C3/C5-Cy); HRMS (TOF MS ES+) calcd for $\mathrm{C}_{27} \mathrm{H}_{32} \mathrm{Cl}_{2} \mathrm{NO}_{4}[\mathrm{M}+\mathrm{H}]^{+} 504.1708$, found 504.1710 .

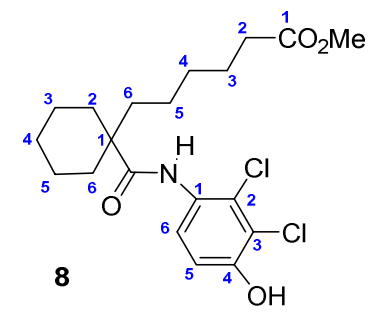

Methyl 6-(1-((2,3-dichloro-4-hydroxyphenyl)carbamoyl)cyclohexyl)hexanoate (8). ${ }^{1} \mathrm{H}$ NMR (300 $\left.\mathrm{MHz}, \mathrm{CDCl}_{3}\right) \delta 7.95(1 \mathrm{H}, \mathrm{d}, J=9 \mathrm{~Hz}, \mathrm{H}-6 \mathrm{Ph}), 7.70(1 \mathrm{H}, \mathrm{br} \mathrm{s}, \mathrm{NH}), 6.90(1 \mathrm{H}, \mathrm{d} J=9 \mathrm{~Hz}, \mathrm{H}-5 \mathrm{Ph}), 6.32(1 \mathrm{H}, \mathrm{br}$ $\mathrm{s}, \mathrm{OH}), 3.64\left(3 \mathrm{H}, \mathrm{s}, \mathrm{CO}_{2} \mathrm{CH}_{3}\right), 2.27(2 \mathrm{H}, \mathrm{t}, \mathrm{J}=7.2 \mathrm{~Hz}, \mathrm{H}-2), 2.04(2 \mathrm{H}, \mathrm{H}-2 / \mathrm{H}-6 \mathrm{Cy}), 1.70-1.20(16 \mathrm{H}, \mathrm{m}, \mathrm{H}-3, \mathrm{H}-$ 4, H-5, H-6 and $8 \mathrm{CH}-\mathrm{Cy}) ;{ }^{13} \mathrm{C} \mathrm{NMR}\left(75 \mathrm{MHz}, \mathrm{CDCl}_{3}\right) \delta 175.2$ (CON), $174.3\left(\mathrm{CO}_{2} \mathrm{H}\right), 149.4$ (C4-Ph), 128.5 (C1Ph), 123.4 (C2-Ph), 122.2 (C3-Ph), 119.1 (C6-Ph), 114.6 (C5-Ph), $51.6\left(\mathrm{OCH}_{3}\right), 47.5$ (C1-Cy), 40.7 (C6), 34.4 (C2/C6-Сy), 33.9 (C2), 29.5 (C4), 25.9 (С4-Сy), 24.7 (С3), 23.6 (С5), 22.9 (С3/С5-Сy). 


\section{Characterization data of intermediates of the synthesis of haptens FHd and FHh}

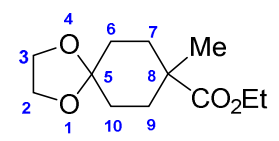

11

Ethyl 8-methyl-1,4-dioxaspiro[4.5]decane-8-carboxylate (11). IR $v_{\max } / \mathrm{cm}^{-1}$ (NaCl) 2953, 2877, 1725, 1446, 1361, 1311, 1203, 1118, 1034, 924; ${ }^{1} \mathrm{H}$ NMR (300 MHz, CDCl $) \delta 4.09\left(2 \mathrm{H}, \mathrm{q}, J=7.1 \mathrm{~Hz}, \mathrm{OCH}_{2} \mathrm{CH}_{3}\right)$, $3.86\left(4 \mathrm{H}, \mathrm{s}, \mathrm{OCH}_{2} \mathrm{CH}_{2} \mathrm{O}\right), 2.07(2 \mathrm{H}, \mathrm{m}, \mathrm{H}-7 / \mathrm{H}-9), 1.67-1.42(6 \mathrm{H}, \mathrm{m}), 1.19\left(3 \mathrm{H}, t, J=7.1 \mathrm{~Hz}, \mathrm{OCH}_{2} \mathrm{CH}_{3}\right), 1.22$ $\left(3 \mathrm{H}, \mathrm{s}, \mathrm{CH}_{3}\right) ;{ }^{13} \mathrm{C} \mathrm{NMR}\left(75 \mathrm{MHz}, \mathrm{CDCl}_{3}\right) \delta 176.8(\mathrm{COO}), 108.3(\mathrm{C} 5), 64.1\left(\mathrm{OCH}_{2} \mathrm{CH}_{2} \mathrm{O}\right), 60.2\left(\mathrm{OCH}_{2} \mathrm{CH}_{3}\right), 42.2$ (C8), 32.7 (C6/C10), 31.9 (C7/C9), $25.9\left(\mathrm{CH}_{3}\right), 14.1\left(\mathrm{OCH}_{2} \mathrm{CH}_{3}\right)$; HRMS (TOF MS ES+) calcd for $\mathrm{C}_{12} \mathrm{H}_{21} \mathrm{O}_{4}$ $[\mathrm{M}+\mathrm{H}]^{+}$229.1440, found 229.1442 .

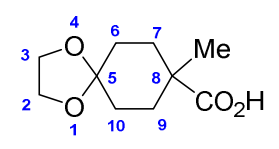

12

8-Methyl-1,4-dioxaspiro[4.5]decane-8-carboxylic acid (12). IR $v_{\max } / \mathrm{cm}^{-1}$ (KBr) 3500-2500, 2952, 2880, 1729, 1698, 1467, 1453, 1244, 1119, 1089, 1038; ${ }^{1} \mathrm{H}$ NMR $\left(300 \mathrm{MHz}, \mathrm{CDCl}_{3}\right) \delta 3.93(4 \mathrm{H}, \mathrm{s}$, $\left.\mathrm{OCH}_{2} \mathrm{CH}_{2} \mathrm{O}\right), 2.13(2 \mathrm{H}, \mathrm{m}, \mathrm{H}-7 / \mathrm{H}-9), 1.69-1.65(4 \mathrm{H}, \mathrm{m}), 1.57-1.31(\mathrm{~m}, 2 \mathrm{H}), 1.25\left(3 \mathrm{H}, \mathrm{s}, \mathrm{CH}_{3}\right) ;{ }^{13} \mathrm{C}$ NMR $(75$ $\mathrm{MHz}, \mathrm{CDCl}_{3}$ ) $\delta 183.7$ (COOH), $108.4(\mathrm{C} 5), 64.2\left(\mathrm{OCH}_{2} \mathrm{CH}_{2} \mathrm{O}\right), 42.2$ (C8), 32.6 (C6/C10), 31.9 (C7/C9), 25.8 $\left(\mathrm{CH}_{3}\right)$. HRMS (TOF MS ES+) calcd for $\mathrm{C}_{10} \mathrm{H}_{20} \mathrm{NaO}_{4}[\mathrm{M}+\mathrm{Na}]^{+} 223.0946$, found 223.0947 .

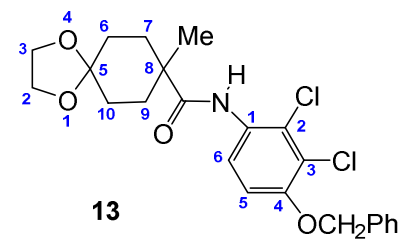

N-(4-(Benzyloxy)-2,3-dichlorophenyl)-8-methyl-1,4-dioxaspiro[4.5]decane-8-carboxamide (13). IR $v_{\max } / \mathrm{cm}^{-1}(\mathrm{NaCl}) 3432,3306,2951,2880,1662,1596,1509,1274,1116,1034 ;{ }^{1} \mathrm{H} \mathrm{NMR}\left(300 \mathrm{MHz}, \mathrm{CDCl}_{3}\right) \delta$ $8.12(1 \mathrm{H}, \mathrm{d}, J=9 \mathrm{~Hz}, \mathrm{H}-6 \mathrm{Ph}), 7.85(1 \mathrm{H}, \mathrm{br} \mathrm{s}, \mathrm{NH}), 7.43-7.28(5 \mathrm{H}, \mathrm{m}, \mathrm{C2}-6 \mathrm{Bn}), 6.90(1 \mathrm{H}, \mathrm{d}, J=9 \mathrm{~Hz}, \mathrm{H}-5 \mathrm{Ph})$, $5.13\left(2 \mathrm{H}, \mathrm{s}, \mathrm{OCH}_{2}\right), 3.93\left(\mathrm{OCH}_{2} \mathrm{CH}_{2} \mathrm{O}\right), 2.15(2 \mathrm{H}, \mathrm{H}-7 / \mathrm{H}-9), 1.72(\mathrm{~m}, 6 \mathrm{H}), 1.31\left(\mathrm{~s}, \mathrm{CH}_{3}\right) ;{ }^{13} \mathrm{C} \mathrm{NMR}^{7} 75 \mathrm{MHz}$, $\mathrm{CDCl}_{3}$ ) $\delta 174.9$ (CON), 151.5 (C4-Ph), 136.1 (C1-Bn), 129.4 (C1 Ph), 128.6 (C3/C5-Bn), 128.1 (C4-Bn), 127.1 (C2/C6-Bn), 123.8 (C2-Ph), 122.3 (C3-Ph), 120.2 (C6-Ph), 112.4 (C5-Ph), 108.1 (C5), $71.4\left(\mathrm{OCH}_{2}\right), 64.2$ $\left(\mathrm{OCH}_{2} \mathrm{CH}_{2} \mathrm{O}\right), 43.2$ (C8), 33.1 (C6/C10), 31.7 (C7/C9), $21.0\left(\mathrm{CH}_{3}\right)$; HRMS (TOF MS ES+) calcd for $\mathrm{C}_{23} \mathrm{H}_{26} \mathrm{Cl}_{2} \mathrm{NO}_{4}[\mathrm{M}+\mathrm{H}]^{+} 450.1239$, found 450.1231 . 


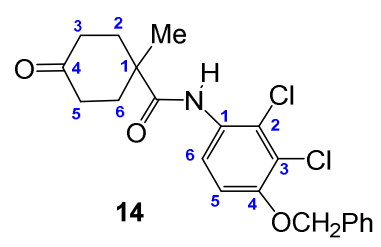

$\mathrm{N}$-(4-(Benzyloxy)-2,3-dichlorophenyl)-1-methyl-4-oxocyclohexanecarboxamide (14). Mp 160-161 ${ }^{\circ} \mathrm{C}$ (from Et ${ }_{2} \mathrm{O}$-hexane). IR $v_{\max } / \mathrm{cm}^{-1}(\mathrm{KBr}) 3231,3090,3009,2948,2903,2864,1709,1644,1572,1510$, 1472, 1454, 1289, 1037; ${ }^{1} \mathrm{H}$ NMR $\left(300 \mathrm{MHz}, \mathrm{CDCl}_{3}\right) \delta 8.12(1 \mathrm{H}, \mathrm{d}, J=9 \mathrm{~Hz}, \mathrm{H}-6 \mathrm{Ph}), 7.87(1 \mathrm{H}, \mathrm{br} \mathrm{s}, \mathrm{NH})$, 7.45-7.35 (5H, m, C2-6 Bn), $6.93(1 \mathrm{H}, \mathrm{d}, J=9 \mathrm{~Hz}, \mathrm{H}-5 \mathrm{Ph}), 5.17\left(2 \mathrm{H}, \mathrm{s}, \mathrm{OCH}_{2}\right), 2.55(2 \mathrm{H}, \mathrm{m}, \mathrm{H}-3 / \mathrm{H}-5), 2.41$

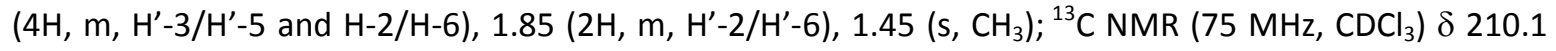
(C4), 173.9 (CON), 151.9 (C4-Ph), 136.0 (C1-Bn), 128.9 (C1 Ph), 128.6 (C3/C5-Bn), 128.2 (C4-Bn), 127.1 (C2/C6-Bn), 124.2 (C2-Ph), 122.5 (C3-Ph), 120.5 (C6-Ph), 112.4 (C5-Ph), $71.4\left(\mathrm{OCH}_{2}\right), 43.2$ (C1), 38.1 (C3/C5), 35.4 (C2/C6), $26.1\left(\mathrm{CH}_{3}\right)$; HRMS (TOF MS ES+) calcd for $\mathrm{C}_{21} \mathrm{H}_{22} \mathrm{Cl}_{2} \mathrm{NO}_{3}[\mathrm{M}+\mathrm{H}]^{+}$406.0981, found 406.0981.

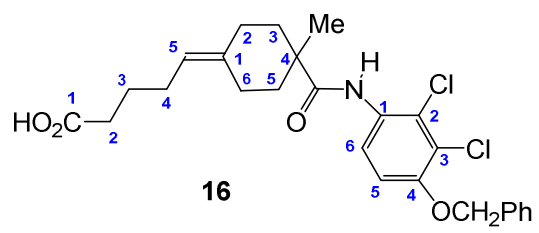

5-(4-((4-(Benzyloxy)-2,3-dichlorophenyl)carbamoyl)-4-methylcyclohexylidene)pentanoic acid (16). IR $v_{\text {max }} / \mathrm{cm}^{-1}(\mathrm{NaCl}) 3500-2400,3430,3033,2928,1707,1593,1509,1469,1273 ;{ }^{1} \mathrm{H}$ NMR $(300 \mathrm{MHz}$, $\left.\mathrm{CDCl}_{3}\right) \delta 8.18(1 \mathrm{H}, \mathrm{d}, J=9.2 \mathrm{~Hz}, \mathrm{H}-6 \mathrm{Ph}), 7.87(1 \mathrm{H}, \mathrm{br} \mathrm{s}, \mathrm{NH}), 7.48-7.29(5 \mathrm{H}, \mathrm{m}, \mathrm{C} 2-6 \mathrm{Bn}), 6.92(1 \mathrm{H}, \mathrm{d}, J=9.2$ $\mathrm{Hz}, \mathrm{H}-5 \mathrm{Ph}), 5.15\left(2 \mathrm{H}, \mathrm{s}, \mathrm{OCH}_{2}\right), 5.13(1 \mathrm{H}, \mathrm{t}, J=7.4, \mathrm{H}-5), 2.36(1 \mathrm{H}, \mathrm{m}, 1 \mathrm{H} \mathrm{Cy}), 2.34(2 \mathrm{H}, t, J=7.4 \mathrm{~Hz}, \mathrm{H}-2)$, 2.23-2.06 (5H, m, 5H Cy), $2.06(2 \mathrm{H}, \mathrm{dt}, J=7.2,7.2 \mathrm{~Hz}, \mathrm{H}-4), 1.68(2 \mathrm{H}$, quint, $J=7.3 \mathrm{~Hz}, \mathrm{H}-3), 1.51(2 \mathrm{H}, \mathrm{m}$, 2H Cy), $1.32\left(3 \mathrm{H}, \mathrm{s}, \mathrm{CH}_{3}\right) ;{ }^{13} \mathrm{C} \mathrm{NMR}\left(75 \mathrm{MHz}, \mathrm{CDCl}_{3}\right) \delta 179.1$ (COOH), 175.3 (CON), 151.5 (C4-Ph), 138.2 (C1-Cy), 136.0 (C1-Bn), 129.4 (C1-Ph), 128.6 (C3/C5-Bn), 128.1 (C4-Bn), 127.1 (C2/C6-Bn), 123.8 (C2-Ph), 122.3 (C3-Ph), 121.3 (C-5), 120.2 (C6-Ph), 112.4 (C5-Ph), $71.4\left(\mathrm{OCH}_{2}\right), 44.4$ (C4-Cy), 37.0 (C3-Cy), 36.2 (C5Cy), 33.3 (C2), 32.9 (C2-Cy), 26.4 (C-4), $26.1\left(\mathrm{CH}_{3}\right), 24.8$ (C3), 24.7 (C6-Cy); HRMS (TOF MS ES+) calcd for $\mathrm{C}_{26} \mathrm{H}_{29} \mathrm{Cl}_{2} \mathrm{NNaO}_{4}[\mathrm{M}+\mathrm{Na}]^{+}$512.1371, found 512.1375. 


\section{Hapten activation and conjugation}

The hapten ( 1 equiv) and DSC (1.1 equiv) were dissolved in anhydrous acetonitrile ( $1 \mathrm{~mL}$ per 0.1 mmol of hapten) under nitrogen in an ice-water bath. $\mathrm{Et}_{3} \mathrm{~N}$ (3.0 equiv) was then added and the resulting mixture was stirred at $0{ }^{\circ} \mathrm{C}$ until complete consumption of the starting material (ca. 1-2 h, TLC using $\mathrm{CHCl}_{3} / \mathrm{MeOH}$ 9:1 as eluent). The reaction mixture was diluted with $\mathrm{CHCl}_{3}$, washed with brine, and dried over anhydrous $\mathrm{Na}_{2} \mathrm{SO}_{4}$. The residue that was obtained after evaporation of the solvent was purified by chromatography, eluting with $\mathrm{CHCl}_{3} / \mathrm{MeOH}$ mixtures from 100:0 to 95:5, to give the corresponding NHS esters in moderate yields.

FHm-NHS ester: ${ }^{1} \mathrm{H}$ NMR $\left(300 \mathrm{MHz}, \mathrm{CDCl}_{3}\right) \delta 8.10(1 \mathrm{H}, \mathrm{d}, J=9 \mathrm{~Hz}, \mathrm{H}-6 \mathrm{Ph}), 7.72(1 \mathrm{H}, \mathrm{br} \mathrm{s}, \mathrm{NH})$, $6.96(1 \mathrm{H}, \mathrm{d}, J=9 \mathrm{~Hz}, \mathrm{H}-5 \mathrm{Ph}), 5.64(1 \mathrm{H}, \mathrm{br} \mathrm{s}, \mathrm{OH}), 2.81\left(\mathrm{br} \mathrm{s}, 4 \mathrm{H}, \mathrm{COCH}_{2} \mathrm{CH}_{2} \mathrm{CO}\right), 2.57(2 \mathrm{H}, \mathrm{t}, J=7.2 \mathrm{~Hz}, \mathrm{H}-$ 2), $2.05(2 \mathrm{H}, \mathrm{m}, \mathrm{H}-2 / \mathrm{H}-6 \mathrm{Cy}), 1.75-1.15(16 \mathrm{H}, \mathrm{m})$.

FHd-NHS ester: ${ }^{1} \mathrm{H}$ NMR (300 MHz, $\left.\mathrm{CDCl}_{3}\right) \delta 8.09(1 \mathrm{H}, \mathrm{d}, J=9.3 \mathrm{~Hz}, \mathrm{H}-6 \mathrm{Ph}), 7.76(1 \mathrm{H}, \mathrm{br} \mathrm{s}, \mathrm{NH})$, $6.96(1 \mathrm{H}, \mathrm{d}, J=9.3 \mathrm{~Hz}, \mathrm{H}-5 \mathrm{Ph}), 5.67(1 \mathrm{H}, \mathrm{br} \mathrm{s}, \mathrm{OH}), 5.12(1 \mathrm{H}, \mathrm{t}, J=7.5, \mathrm{H}-5), 2.84\left(\mathrm{br} \mathrm{s}, 4 \mathrm{H}, \mathrm{COCH}_{2} \mathrm{CH}_{2} \mathrm{CO}\right)$, $2.60(2 \mathrm{H}, t, J=7.5 \mathrm{~Hz}, \mathrm{H}-2), 2.37(1 \mathrm{H}, \mathrm{m}, 1 \mathrm{H} \mathrm{Cy}), 2.22-2.10(7 \mathrm{H}, \mathrm{m}, 5 \mathrm{H}$ Cy and $\mathrm{H}-4), 1.79(2 \mathrm{H}$, quint, $J=7.5$ $\mathrm{Hz}, \mathrm{H}-3), 1.54(2 \mathrm{H}, \mathrm{m}, 2 \mathrm{H} \mathrm{Cy}), 1.32\left(3 \mathrm{H}, \mathrm{s}, \mathrm{CH}_{3}\right)$.

FHh-NHS ester: A ca. 60:40 mixture of epimers was obtained. ${ }^{1} \mathrm{H}$ NMR (300 MHz, $\mathrm{CDCl}_{3}$ ) (only signals of one of the epimers are given) $\delta 8.07(1 \mathrm{H}, \mathrm{d}, J=9 \mathrm{~Hz}, \mathrm{H}-6 \mathrm{Ph}), 7.74(1 \mathrm{H}, \mathrm{br} \mathrm{s}, \mathrm{NH}), 6.93(1 \mathrm{H}, \mathrm{d}, J=$ $9.1 \mathrm{~Hz}, \mathrm{H}-5 \mathrm{Ph}), 5.91(1 \mathrm{H}, \mathrm{br} \mathrm{s}, \mathrm{OH}), 2.84$ (br s, 4H, $\left.\mathrm{COCH}_{2} \mathrm{CH}_{2} \mathrm{CO}\right), 2.62(2 \mathrm{H}, t, J=7.2 \mathrm{~Hz}, \mathrm{H}-2), 2.22(2 \mathrm{H}, \mathrm{m}$, $\mathrm{H}-3 / \mathrm{H}-5 \mathrm{Cy}), 1.80-1.65(6 \mathrm{H}, \mathrm{m}, \mathrm{H}-3, \mathrm{H}-5$ and $2 \mathrm{H} \mathrm{Cy}), 1.5-1.03(7 \mathrm{H}, \mathrm{m}, 7 \mathrm{H} \mathrm{Cy}), 1.31\left(3 \mathrm{H}, \mathrm{s}, \mathrm{CH}_{3}\right)$.

The purified active esters of the haptens were dissolved in dry $\mathrm{N}, \mathrm{N}$-dimethylformamide and slowly added to the corresponding protein solution in $50 \mathrm{mM}$ carbonate-bicarbonate buffer, pH 9.6. BSA, OVA, and HRP were used as carriers for immunogen, coating conjugate, and enzyme tracer preparation, respectively. For BSA coupling, 30 moles of pure active ester were applied per umole of carrier protein, whereas for OVA conjugation 3 umoles of activated hapten were used per mole of protein. Enzyme tracers were obtained by adding a 10-fold molar excess of pure activated hapten to the HRP solution. Conjugation was carried out at $\mathrm{rt}$ during $2 \mathrm{~h}$ with gentle stirring, and bioconjugates were purified by size exclusion chromatography using desalting columns and $100 \mathrm{mM}$ phosphate buffer, $\mathrm{pH} 7.4$, as eluent. 

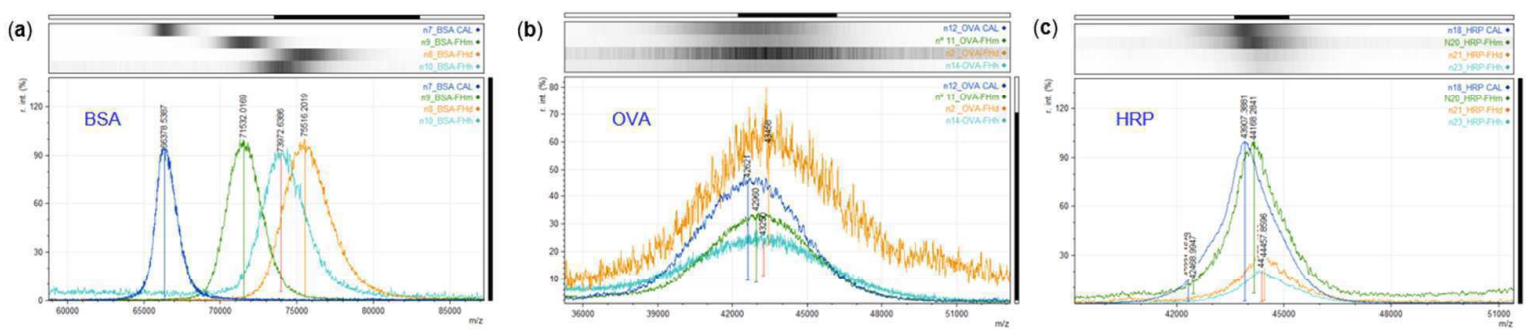

\begin{tabular}{|c|c|c|c|c|}
\cline { 2 - 5 } \multicolumn{1}{c|}{} & $m / z$ & $\Delta m /$ hapten & $\Delta(m / z)$ & MR \\
\hline BSA & 66378 & - & - & - \\
\hline BSA-FHm & 71532 & 383.1 & 5154 & 13.4 \\
\hline BSA-FHd & 75516 & 381.1 & 9138 & 24.0 \\
\hline BSA-FH $h$ & 73973 & 383.1 & 7595 & 19.8 \\
\hline
\end{tabular}

\begin{tabular}{|c|c|c|c|c|}
\cline { 2 - 5 } \multicolumn{1}{c|}{} & $m / z$ & $\Delta m /$ hapten & $\Delta(m / z)$ & MR \\
\hline OVA & 42621 & - & - & - \\
\hline OVA-FHm & 42960 & 3831 & 339 & 0.9 \\
\hline OVA-FHd & 43458 & 381.1 & 837 & 2.2 \\
\hline OVA-FH $h$ & 43250 & 383.1 & 629 & 1.6 \\
\hline
\end{tabular}

\begin{tabular}{|c|c|c|c|c|}
\cline { 2 - 5 } \multicolumn{1}{c|}{} & $m / \mathbf{z}$ & $\Delta m /$ hapten & $\Delta(m / z)$ & MR \\
\hline HRP & 43907 & - & - & - \\
\hline HRP-FHm & 44168 & 383.1 & 261 & 0.7 \\
\hline HRP-FHd & 44457 & 381.1 & 550 & 1.4 \\
\hline HRP-FHh & 44377 & 383.1 & 470 & 1.2 \\
\hline
\end{tabular}

Figure S1. MALDI-TOF spectra of a) BSA conjugates, b) OVA conjugates, and c) HRP conjugates of novel fenhexamid haptens. (Reference proteins are depicted in blue line, $\mathrm{FHm}$ conjugates in green line, $\mathrm{FH} d$ conjugates in orange line and $\mathrm{FH} h$ conjugates in cyan line).

\section{Monoclonal antibody generation}

Immunization. BALB/c female mice (8-10 weeks old) were immunized with the BSA conjugates by intraperitoneal injections. Doses consisted of an emulsion of $100 \mu \mathrm{L}$ of PB containing $100 \mu \mathrm{g}$ of protein conjugate and $100 \mu \mathrm{L}$ of Freund's adjuvant. The first dose contained complete Freund's adjuvant, and subsequent doses were given at weeks 3 and 6 using incomplete Freund's adjuvant. After a resting period of at least 3 weeks from the last injection with adjuvant and four days before cell fusion, mice received a booster intraperitoneal injection of $200 \mu \mathrm{L}$ of a 1:1 mixture of PBS and a solution containing $100 \mu \mathrm{g}$ of BSA-hapten conjugate in PB.

Cell fusion and culture. P3-X63/Ag 8.653 murine myeloma cells were cultured in high-glucose DMEM supplemented with $2 \mathrm{mM}$ alanylglutamine, $1 \mathrm{mM}$ MEM nonessential amino acids, and $25 \mu \mathrm{g} / \mathrm{mL}$ gentamycin (referred to as s-DMEM) and containing $10 \%(\mathrm{v} / \mathrm{v})$ foetal bovine serum (FBS). Just before spleen extraction, mouse blood was collected by heart puncture and the serum was diluted 1/10 with storage buffer and kept at $4{ }^{\circ} \mathrm{C}$. After cytolysis of red blood cells by osmotic shock, mouse spleen lymphocytes were fused with myeloma cells at a 4:1 ratio using $1 \mathrm{~mL}$ of PEG 1500 as the fusing agent. The fused cells were distributed in 96-well culture plates at a density between $1.5 \times 10^{5}$ and $2.5 \times 10^{5}$ cells per well in $100 \mu \mathrm{L}$ of s-DMEM with $15 \%$ FBS. Sixteen hours after plating, $100 \mu \mathrm{L}$ of HAT selection medium was added to each well.

Hybridoma selection and cloning. Twelve days after fusion, hybridoma culture supernatants were screened by differential indirect cELISA with $1.0 \mu \mathrm{g} / \mathrm{mL}$ homologous OVA coating conjugate. RAM-HRP conjugate from Dako (Glostrup, Denmark) was employed to detect the immunological reaction. The signal of each blank assay was compared with the corresponding competitive result when $0.1 \mu \mathrm{M}$ 
1

2

3

4

5

6

7

8

9

fenhexamid was used as competitor. Supernatants affording a high ratio between the absorbance of both assays or with saturated signals were rescreened by checkerboard indirect cELISA. Homologous conjugate-coated plates (at 0.1 and $1.0 \mu \mathrm{g} / \mathrm{mL}$ ) were employed and serial supernatant and fenhexamid dilutions were combined and assayed. Detected high-affinity antibody-producing hybridomas were cloned by limiting dilution in HT medium containing $20 \%$ FBS and $1 \%$ HFCS. Stable clones were expanded and cryopreserved in liquid nitrogen.

\begin{tabular}{|c|c|c|c|c|c|}
\hline \multicolumn{6}{|c|}{$\begin{array}{l}\text { Table S1 } \\
\text { Immunoassay conditions and standard curve parameters for } \\
\text { fenhexamid determination }\end{array}$} \\
\hline \multirow[b]{2}{*}{$m A b$} & \multirow{2}{*}{$\begin{array}{l}{[\mathrm{mAb}]} \\
(\mu \mathrm{g} / \mathrm{L})\end{array}$} & \multirow[b]{2}{*}{ Tracer } & \multicolumn{2}{|c|}{$[T]^{a}$} & \multirow{2}{*}{$\begin{array}{c}\mathrm{IC}_{50} \\
(\mu \mathrm{g} / \mathrm{L})\end{array}$} \\
\hline & & & $(\mu \mathrm{g} / \mathrm{L})$ & $A_{\max }$ & \\
\hline \multirow[t]{4}{*}{$\mathrm{FHm \# 110}$} & 1000 & $\mathrm{HRP}-\mathrm{FH} m$ & 30 & 1.63 & 0.14 \\
\hline & 1000 & HRP-FHd & 30 & 1.48 & 0.14 \\
\hline & 1000 & HRP-FH $h$ & 30 & 1.59 & 0.16 \\
\hline & 1000 & HRP_FHo & 100 & $---b$ & --- \\
\hline \multirow[t]{4}{*}{$\mathrm{FHm \# 113}$} & 1000 & HRP-FHm & 10 & 0.86 & 0.05 \\
\hline & 1000 & HRP-FHd & 10 & 1.12 & 0.07 \\
\hline & 1000 & HRP-FH $h$ & 10 & 1.00 & 0.09 \\
\hline & 1000 & HRP_FHo & 100 & $--^{c}$ & --- \\
\hline \multirow[t]{4}{*}{ FHm\#114 } & 1000 & HRP-FHm & 100 & 1.02 & 0.02 \\
\hline & 1000 & HRP-FHd & 100 & 0.61 & 0.05 \\
\hline & 1000 & HRP-FH $h$ & 30 & 1.33 & 0.02 \\
\hline & 1000 & HRP_FHo & 100 & -- & -- \\
\hline \multirow[t]{4}{*}{$\mathrm{FHd \# 19}$} & 1000 & HRP-FHm & 10 & 1.42 & 0.39 \\
\hline & 1000 & HRP-FHd & 3 & 0.82 & 0.60 \\
\hline & 1000 & HRP-FH $h$ & 10 & 1.08 & 0.52 \\
\hline & 1000 & HRP_FHo & 100 & -- & --- \\
\hline \multirow[t]{4}{*}{ FHd\#132 } & 1000 & $\mathrm{HRP}-\mathrm{FH} m$ & 100 & 0.71 & 0.08 \\
\hline & 1000 & HRP-FHd & 30 & 1.27 & 0.08 \\
\hline & 1000 & HRP-FH $h$ & 30 & 0.95 & 0.18 \\
\hline & 1000 & HRP-FHo & 100 & --- & --- \\
\hline \multirow[t]{4}{*}{ FHd\#139 } & 1000 & HRP_FHm & 30 & 1.85 & 0.10 \\
\hline & 1000 & HRP_FHd & 10 & 1.56 & 0.12 \\
\hline & 1000 & HRP-FH $h$ & 30 & 1.89 & 0.17 \\
\hline & 1000 & HRP_FHo & 100 & -- & -- \\
\hline \multirow[t]{4}{*}{$\mathrm{FH} h \# 15$} & 1000 & HRP_FHm & 100 & 1.21 & 0.04 \\
\hline & 1000 & HRP_FHd & 100 & 0.79 & 0.10 \\
\hline & 1000 & $\mathrm{HRP}-\mathrm{FH} h$ & 30 & 1.19 & 0.04 \\
\hline & 1000 & $\mathrm{HRP}-\mathrm{FHo}$ & 100 & --- & --- \\
\hline \multirow[t]{4}{*}{$\mathrm{FH} h \# 122$} & 1000 & $\mathrm{HRP}-\mathrm{FH} m$ & 100 & -- & -- \\
\hline & 1000 & HRP-FHd & 100 & 0.57 & 0.18 \\
\hline & 1000 & $\mathrm{HRP}-\mathrm{FH} h$ & 100 & 0.92 & 0.08 \\
\hline & 1000 & HRP-FHo & 100 & -- & --- \\
\hline \multirow[t]{4}{*}{$\mathrm{FH} h \# 130$} & 1000 & $\mathrm{HRP}-\mathrm{FH} m$ & 100 & 0.52 & 0.11 \\
\hline & 1000 & HRP-FHd & 100 & --- & --- \\
\hline & 1000 & HRP-FHh & 30 & 0.85 & 0.08 \\
\hline & 1000 & HRP-FHo & 100 & -- & -- \\
\hline \multirow[t]{4}{*}{ FHo\#22 } & 1000 & $\mathrm{HRP}-\mathrm{FH} m$ & 100 & --- & --- \\
\hline & 1000 & HRP-FHd & 100 & --- & --- \\
\hline & 1000 & HRP-FH $h$ & 100 & --- & --- \\
\hline & 1000 & HRP_FHo & 30 & 1.92 & 0.93 \\
\hline \multirow[t]{4}{*}{ FHo\#26 } & 1000 & HRP-FHm & 100 & --- & --- \\
\hline & 1000 & HRP_FHd & 100 & --- & --- \\
\hline & 1000 & HRP_FHh & 100 & .-- & -.- \\
\hline & 1000 & HRP-FHo & 10 & 1.29 & 0.66 \\
\hline \multirow[t]{4}{*}{ FHo\#27 } & 1000 & HRP-FHm & 100 & -- & --- \\
\hline & 1000 & HRP-FHd & 100 & --- & --- \\
\hline & 1000 & HRP-FH $h$ & 100 & -- & --- \\
\hline & 1000 & HRP-FHo & 10 & 1.55 & 0.69 \\
\hline
\end{tabular}

a Enzyme tracer concentration. ${ }^{\mathrm{b}} \mathrm{A}_{\max }$ value was lower than 0.5 . 
Table S2

Precision of the standard curve

\begin{tabular}{lcc}
\hline & \multicolumn{2}{c}{ RSD (\%) } \\
\cline { 2 - 3 } Parameter & Intra-day $^{\mathrm{a}}$ & Inter-day $^{\mathrm{b}}$ \\
\hline $\mathrm{A}_{\max }$ & 4.2 & 5.5 \\
Slope & 6.9 & 9.5 \\
$\mathrm{IC}_{50}$ & 6.5 & 5.5 \\
\hline${ }^{\mathrm{a}} \mathrm{n}=5 .{ }^{\mathrm{b}} \mathrm{n}=3$. & &
\end{tabular}
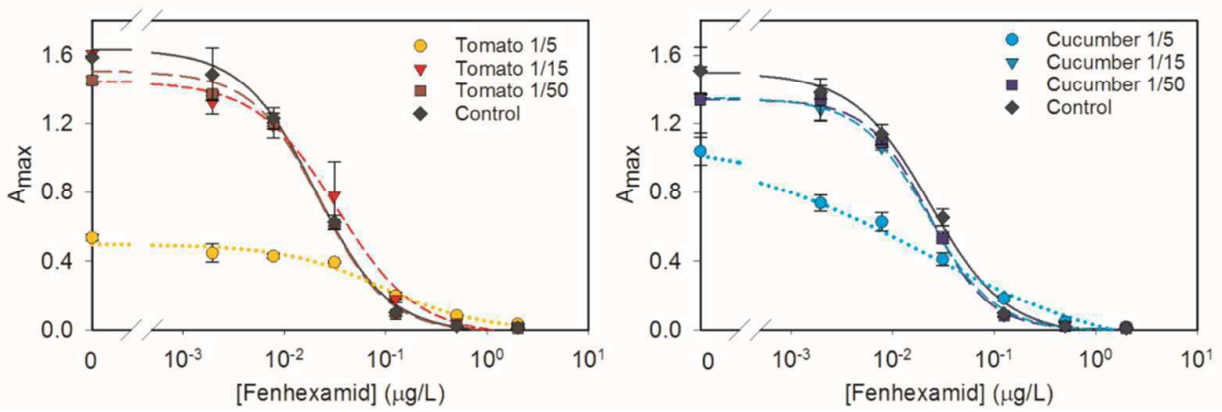

Figure S2. Matrix interferences with diluted tomato and cucumber QuEChERS extracts over the studied cELISA.

\section{Table S3}

Determination of fenhexamid residues in tomato $(\mathrm{T})$ and cucumber $(\mathrm{C})$ samples by the developed CELISA and a reference chromatographic method.

\begin{tabular}{cccc}
\hline & & {$[$ [Fenhexamid] $(\mu \mathrm{g} / \mathrm{kg} \pm \mathrm{s}, \mathrm{n}=3)$} \\
\cline { 2 - 4 } Type & Sample & cELISA & UPLC-MS/MS \\
\hline In-field & T1 & $580 \pm 60$ & $650 \pm 80$ \\
treated & T2 & $490 \pm 70$ & $510 \pm 80$ \\
& T3 & $190 \pm 30$ & $180 \pm 30$ \\
& T4 & $430 \pm 70$ & $480 \pm 90$ \\
& T5 & $330 \pm 30$ & $310 \pm 70$ \\
& C1 & $870 \pm 30$ & $700 \pm 100$ \\
& C2 & $1000 \pm 300$ & $1000 \pm 100$ \\
& C3 & $110 \pm 30$ & $70 \pm 10$ \\
& C4 & $150 \pm 20$ & $100 \pm 10$ \\
& C5 & $112 \pm 20$ & $28 \pm 5$ \\
Blind & T6 & $19 \pm 4$ & $21 \pm 1$ \\
spiked & T7 & $70 \pm 9$ & $81 \pm 2$ \\
& T8 & $1400 \pm 300$ & $1300 \pm 100$ \\
& T9 & $900 \pm 100$ & $800 \pm 100$ \\
& T10 & $700 \pm 100$ & $560 \pm 7$ \\
& T11 & $290 \pm 20$ & $290 \pm 40$ \\
& T12 & $210 \pm 30$ & $190 \pm 20$ \\
& T13 & $110 \pm 20$ & $120 \pm 20$ \\
& C6 & $100 \pm 20$ & $100 \pm 3$ \\
& C7 & $1100 \pm 100$ & $1000 \pm 100$ \\
& C8 & $800 \pm 100$ & $680 \pm 40$ \\
C9 & $90 \pm 10$ & $110 \pm 20$ \\
& C10 & $24 \pm 2$ & $24 \pm 2$ \\
C11 & $71 \pm 8$ & $75 \pm 2$ \\
C12 & $280 \pm 30$ & $250 \pm 30$ \\
C13 & $1300 \pm 100$ & $1100 \pm 100$ \\
\hline
\end{tabular}




\section{${ }^{1} \mathrm{H}$ NMR of hapten $\mathrm{FHm}\left(\mathrm{CD}_{3} \mathrm{OD}, 300 \mathrm{MHz}\right)$}

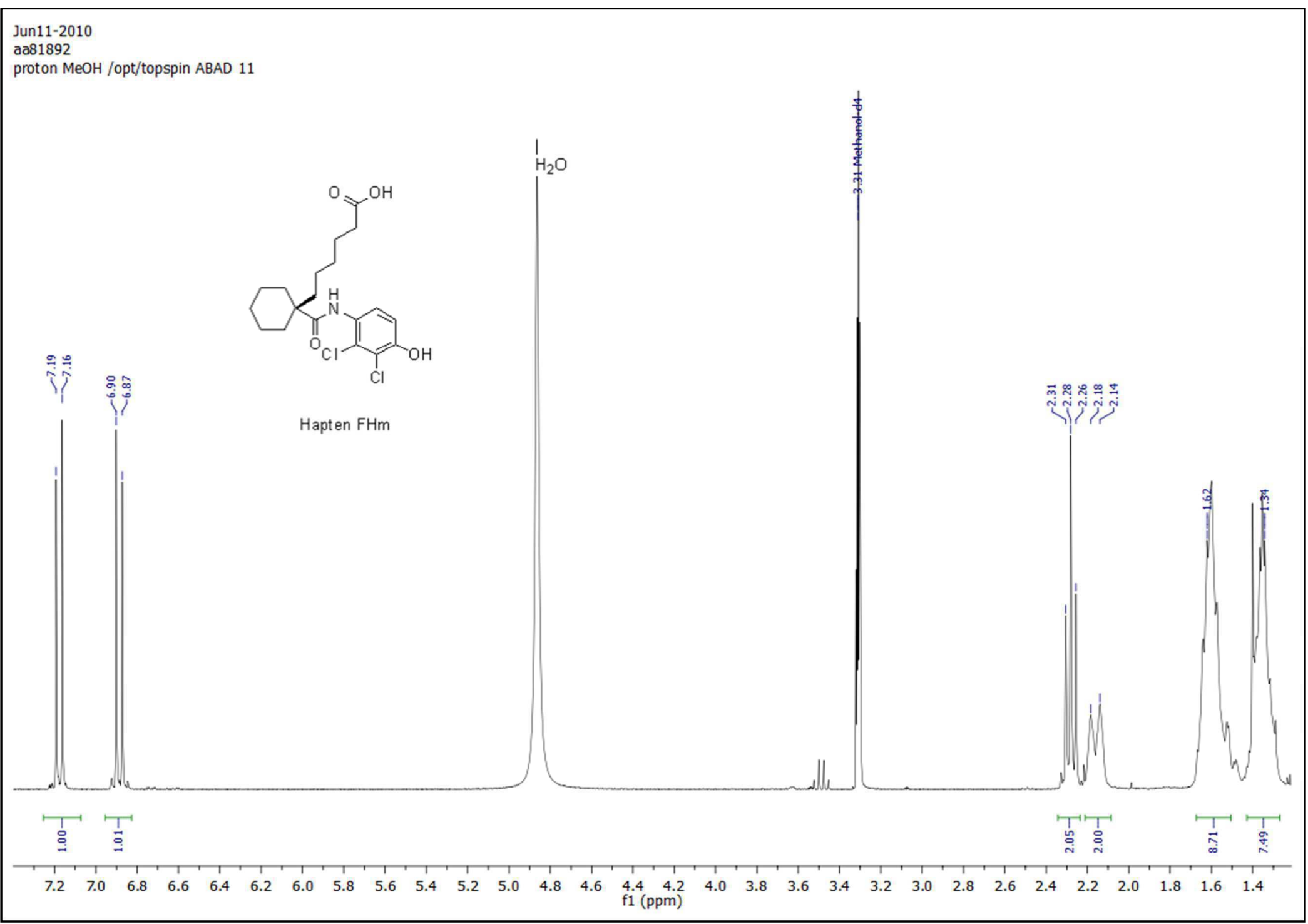


${ }^{1} \mathrm{H}$ NMR of $\mathrm{FH} m$-NHS ester $\left(\mathrm{CDCl}_{3}, 300 \mathrm{MHz}\right)$

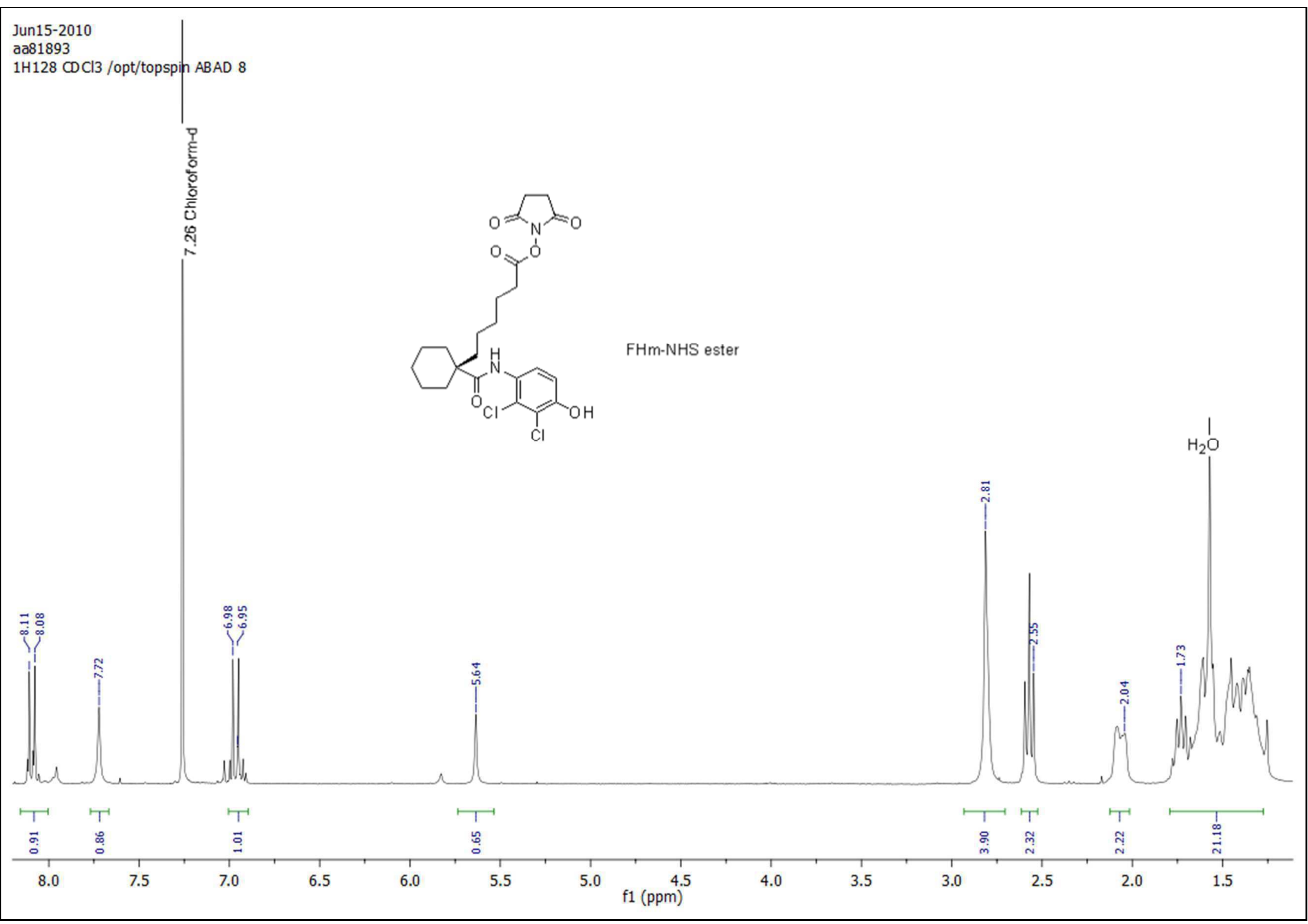


${ }^{1} \mathrm{H}$ NMR of hapten $\mathrm{FHd}\left(\mathrm{CDCl}_{3}, 300 \mathrm{MHz}\right)$

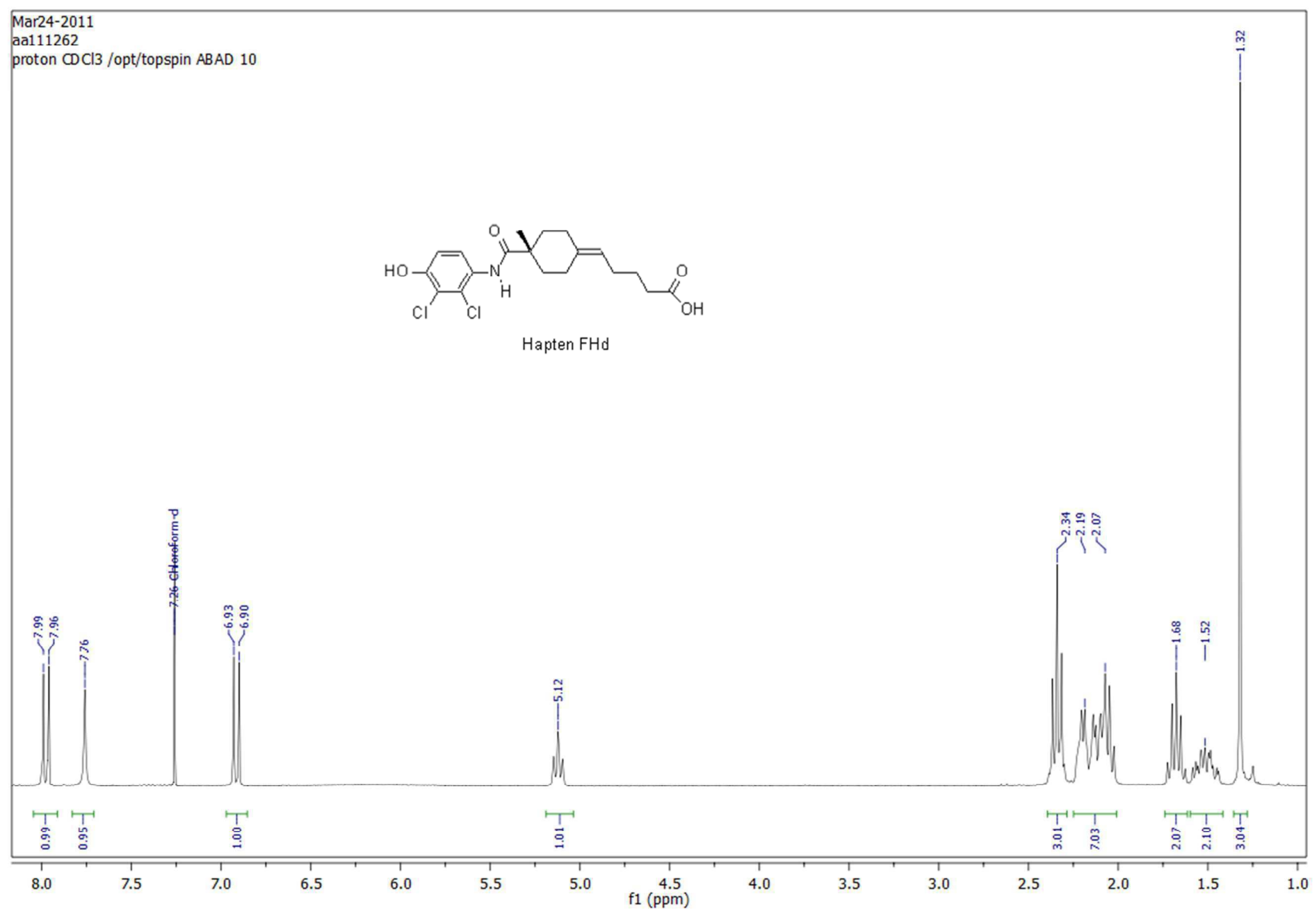


${ }^{1} \mathrm{H}$ NMR of $\mathrm{FHd}$-NHS ester $\left(\mathrm{CDCl}_{3}, 300 \mathrm{MHz}\right)$

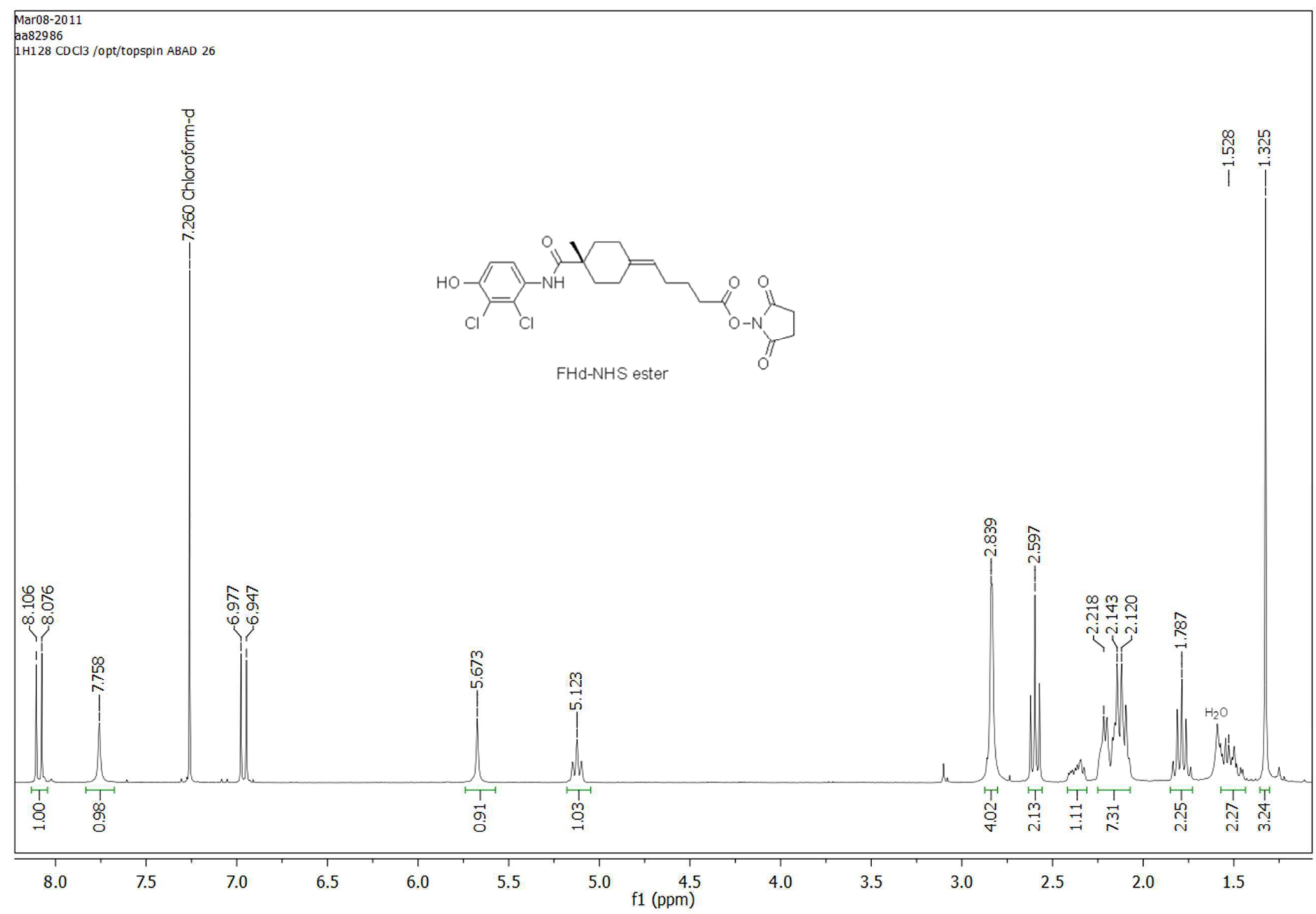




\section{${ }^{1} \mathrm{H}$ NMR of hapten $\mathrm{FH} h\left(\mathrm{CDCl}_{3}, 300 \mathrm{MHz}\right)$}

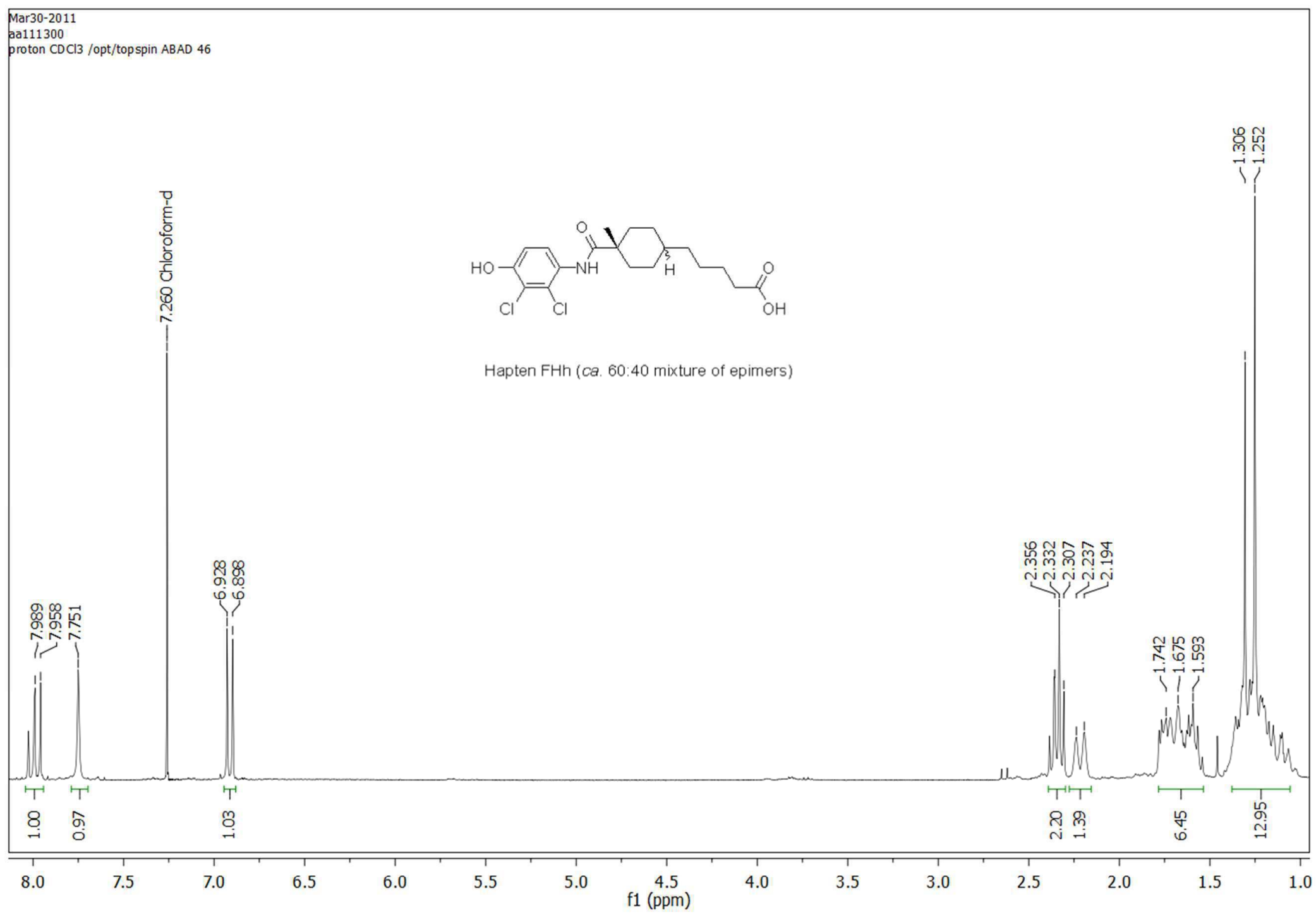


${ }^{1} \mathrm{H}$ NMR of $\mathrm{FH} h$-NHS ester $\left(\mathrm{CDCl}_{3}, 300 \mathrm{MHz}\right)$

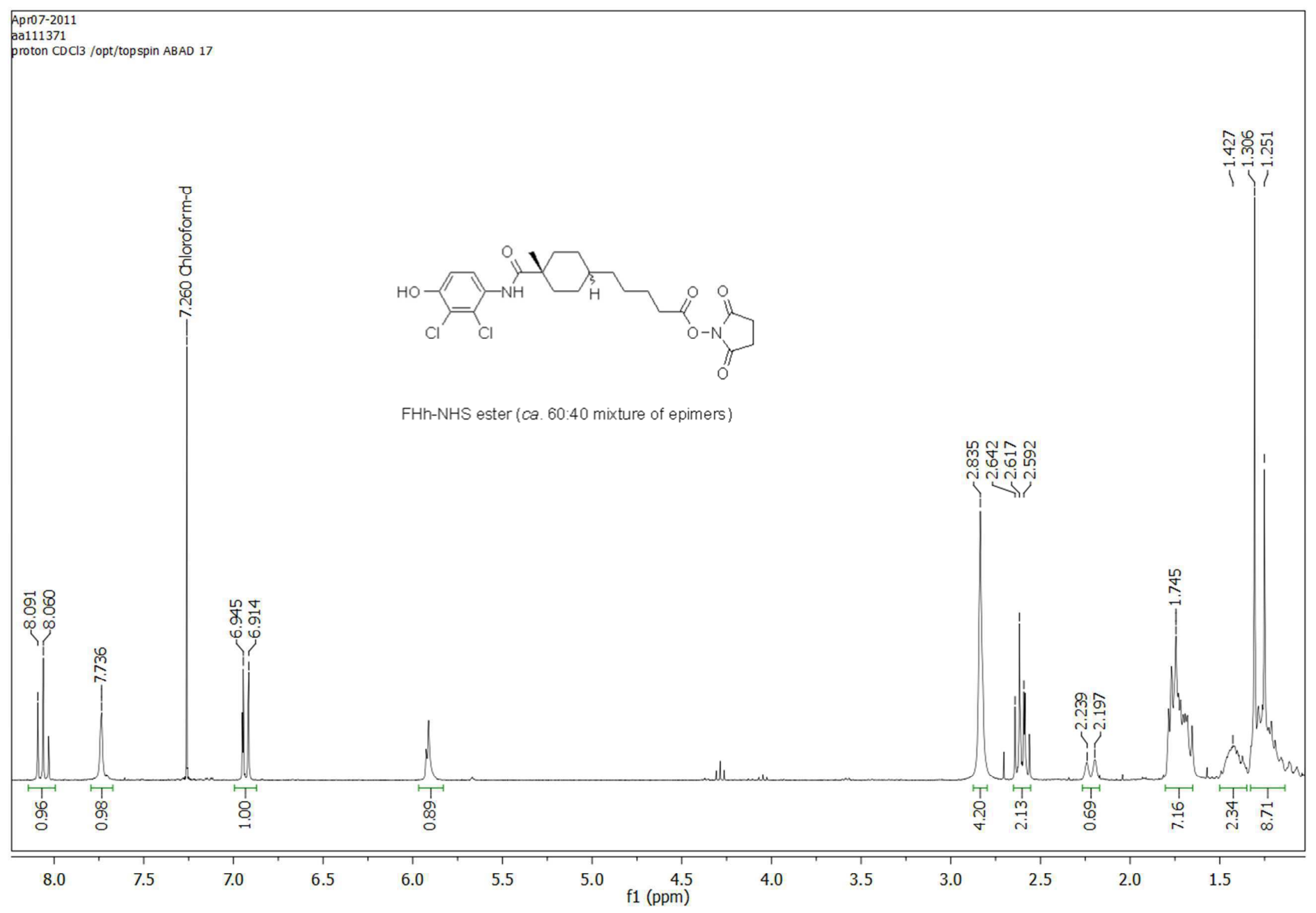

